\title{
INDICATIVE PERFORMANCE COMPETENCIES FOR SOCIAL WORKERS IN THE SULTANATE'S SCHOOLS: PRINCIPALS AND SOCIAL SUPERVISORS' PERSPECTIVES
}

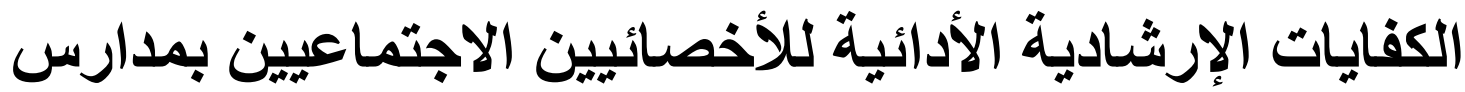

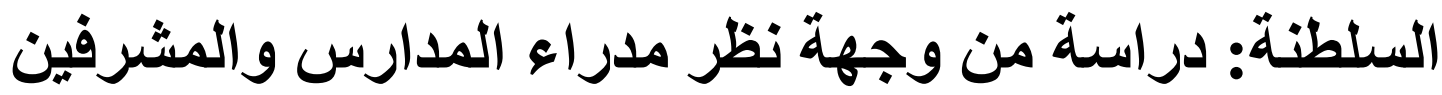 \\ الإجتماعين$$
\text { موسى الشعيلي }
$$ \\ Alshuaili Moosa Suliaman Khalafan ${ }^{1 *}$, \& Siti Rafiah Abdulhamid ${ }^{2}$ \\ ${ }^{1} \mathrm{Ph} . \mathrm{D}$. Candidate at the Faculty of Education, International Islamic University- Malaysia (IIUM), \\ shuailiy@aou.edu.om \\ ${ }^{2}$ Assoc. Prof. Dr., Faculty of Education, International Islamic University- Malaysia (IIUM), \\ srafiah60@iium.edu.my \\ ${ }^{*}$ Corresponding Author
}

\begin{abstract}
This quantitative study discussed the indicative efficiencies of social workers in the Sultanate's schools. The problem was: studies conducted on social workers in the school indicated that; they need more training in vocational competencies. They complain of poor qualification, their need for indicative performance competencies. The objective of the study; to diagnose the indicative performance competencies for social workers, and to detect any statistically significant differences in the average of specialists' ability according to the variables. A random sample was chosen from Muscat Governorate, Al Dakhiliyah Region, and South Al Batinah Region, amounting to (312) social education directors and supervisors. A questionnaire was developed consisting of (68) items distributed in (7) fields. Descriptive analysis and mono-variance analysis were adopted. The findings showed that: the social workers possess a high degree in the field of personal characteristics in the first place, communication and external relations, then the field of collective guidance, then the field of documentation and registration. It was a moderate degree in the areas of: individual counseling and skills, then the scope of the guiding plan, and finally the field of group counseling. The results also indicated that there are statistically significant differences for the gender variable in favor of females in the performance of guiding performance competencies, as well as for the qualification variable and in favor of a bachelor's degree, and the educational district in favor of the Governorate of Muscat, and in favor of school administrators.
\end{abstract}

Keywords: performance competencies, social workers, school administrators, supervisors

$$
\text { الملخص }
$$

نافثت هذه الدر اسة الكمية الكفايات الإرشادية الأدائية للأخصائيين الاجتماعيين بمدارس السلطنة. برزت المشكلة: أنَّ كثبر من الدر اسـات التي أجريت على الأخصـائيين الاجتمـاعبين في المجـال 


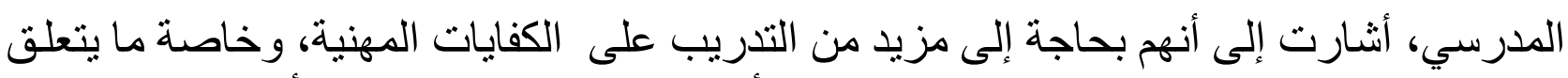

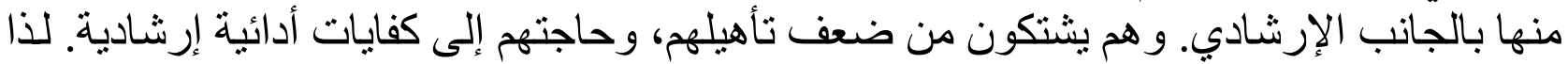

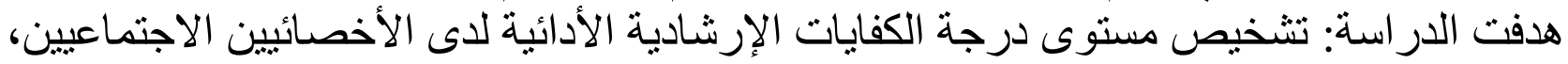

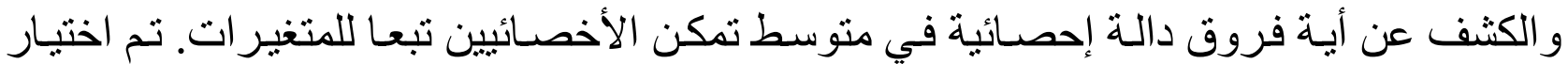

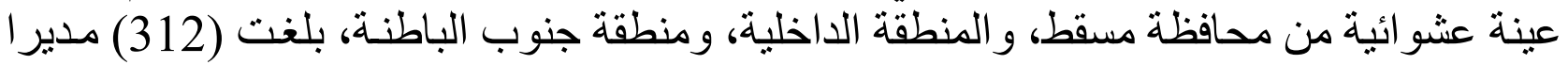

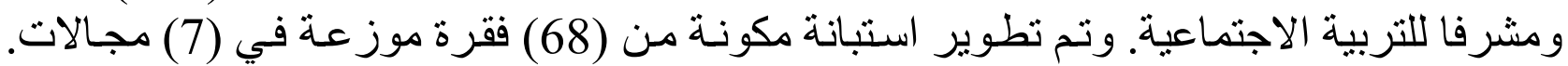

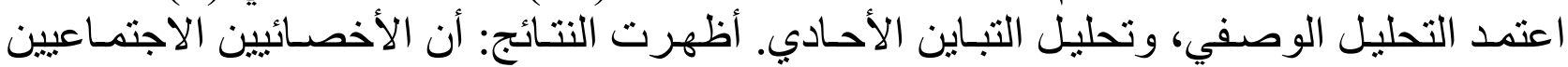

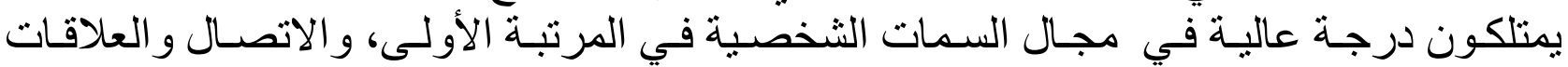

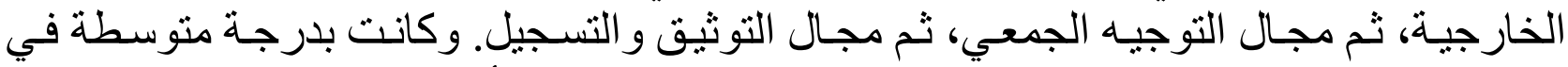

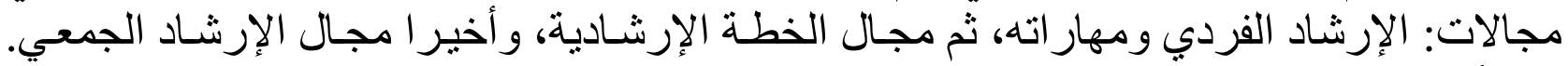

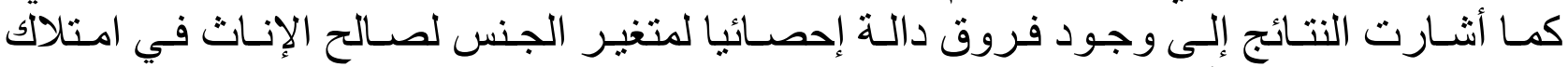

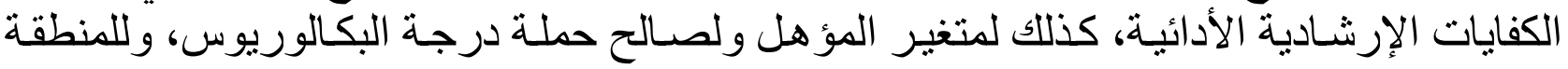

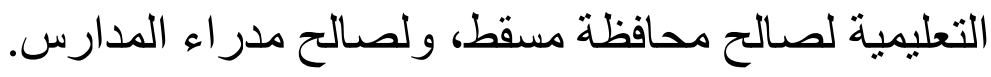

الكلمات المفتاحية: الكفايات الأدائية، الأخصائيين الاجتماعيين، مدر اء المدارس، الماءر، المشرفون

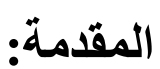

تساير الأنظمة التربوية حركة التطوير التي تمر بها المجتمعات، فنرى أن مشكلات الطلبة ليست

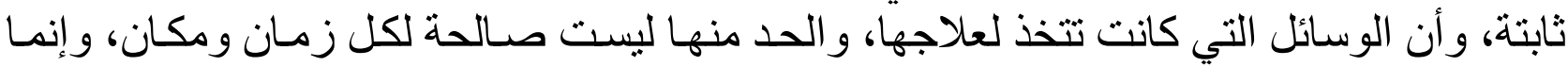

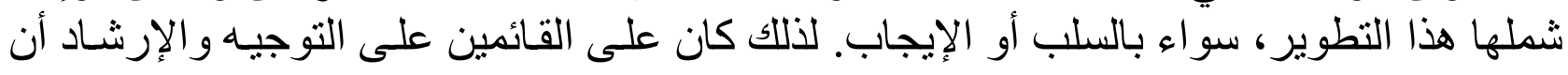

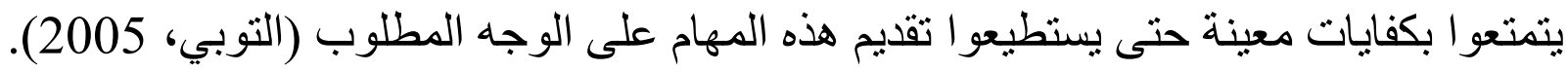

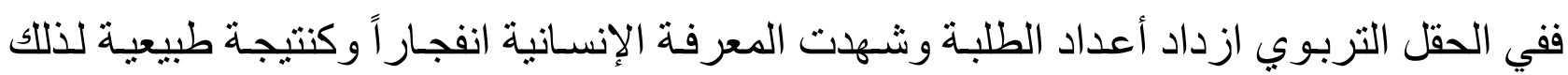

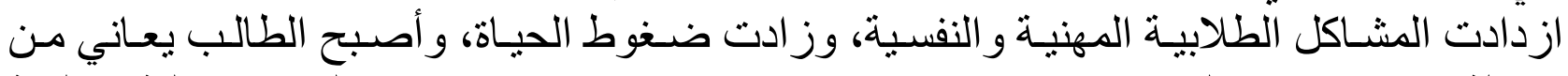

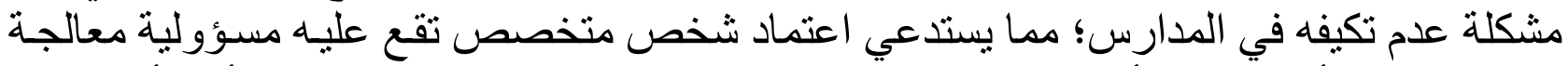

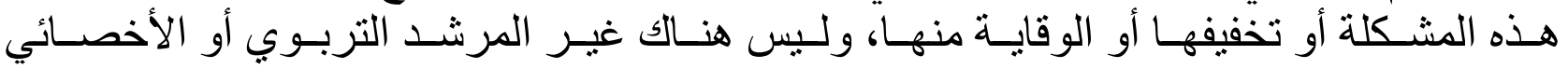

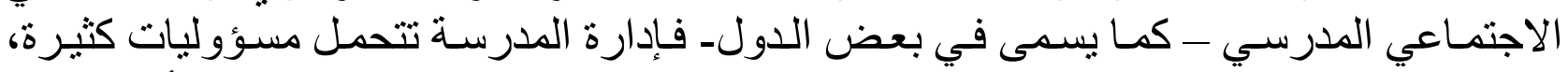

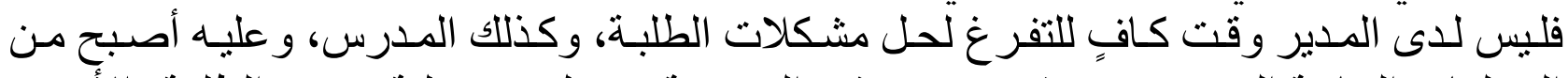

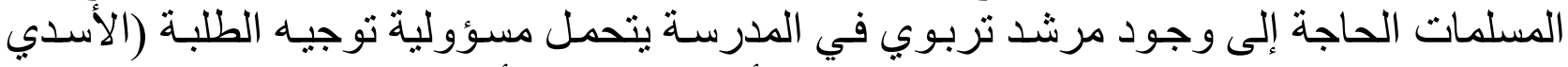

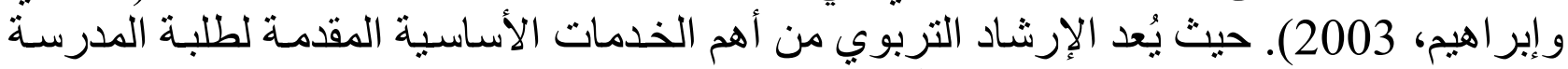

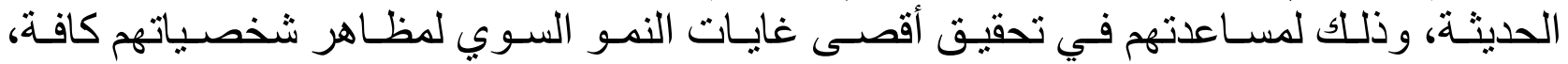

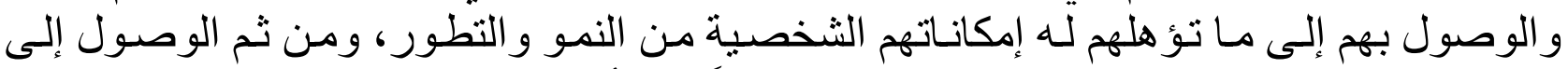

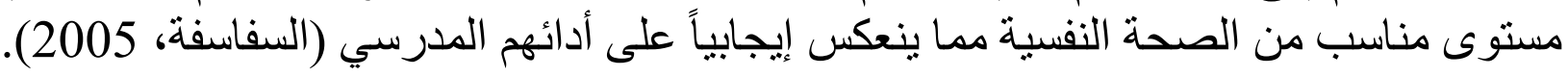

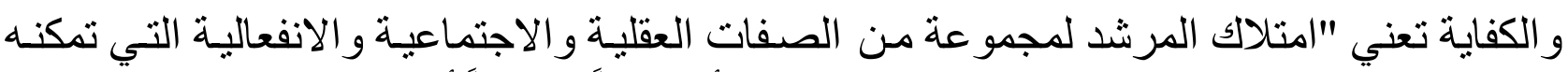

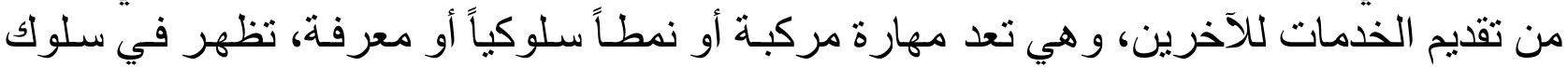

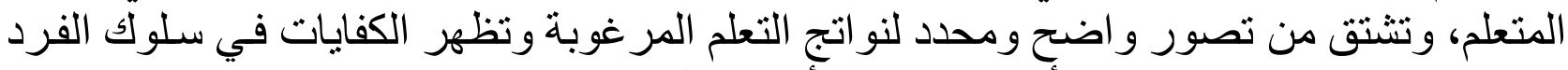

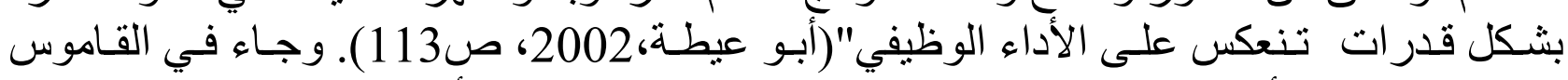

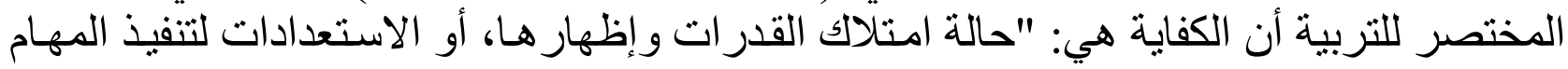

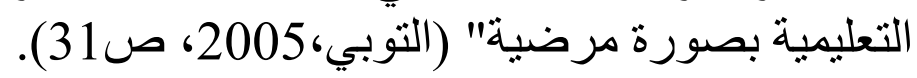




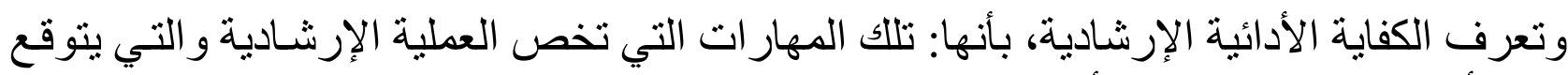
من الأخصائيين الاجتماعيين أن بظهرو ها في عملهم ويمكن ملاحظتها، للتعرف على مدى نلى تمكنهم

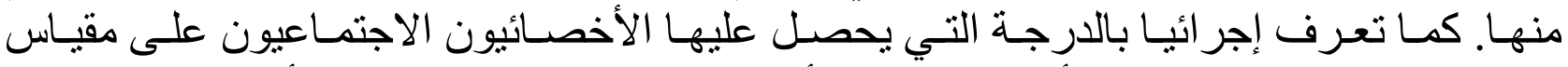

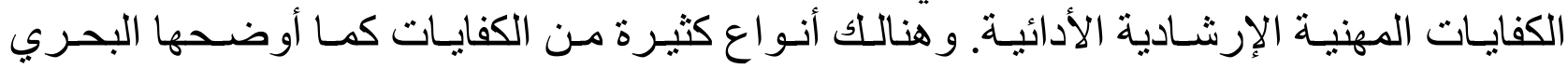
(2006). و هي تتمثل في المعسارف و الخبر ات و المهار ات و الصفات الثخصية وكفابـات متعلقة

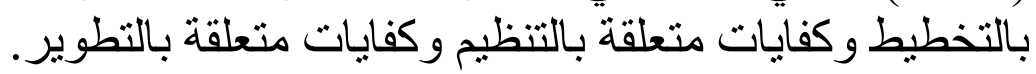

لقد هدفت السياسة التربوية في سلطنة عمان إلى تنويع التعليم، والارتقاء بنو عيته؛ لمو اجهة حركة

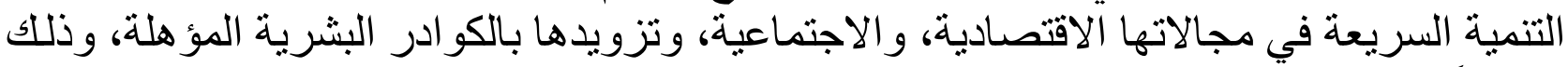

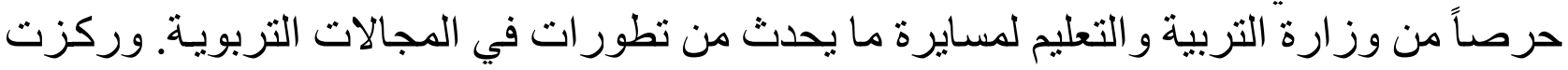

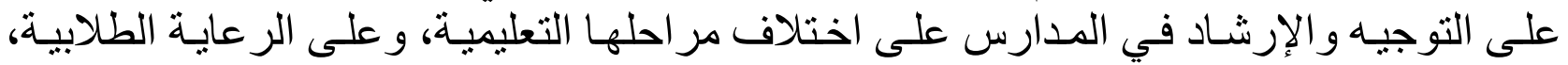

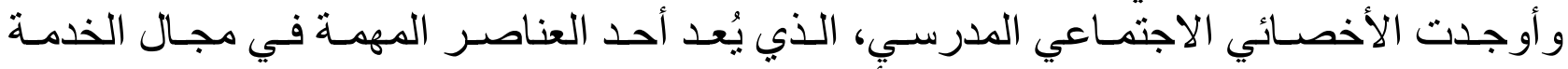

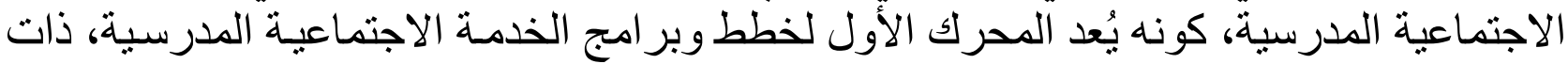

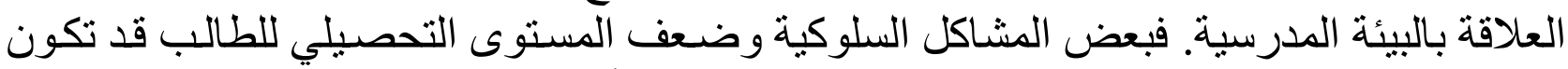
نتاج المو اقف الاجتماعية التي يتعرض لها، وضعف التهفية دور الأسرة في علاج هذه المو اقف يضـع كل العبء على الأخصائي الاجتماعي في المدرسة (الثقصسي، 2007).

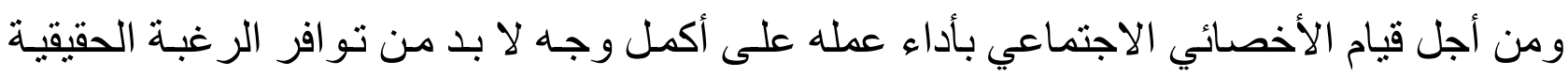

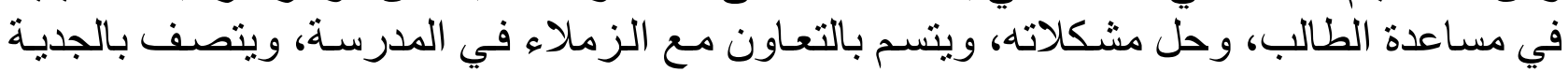

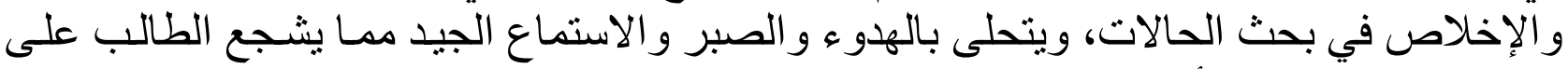

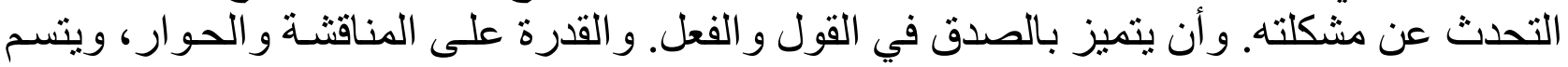
بالموضو عية في كلامه و عدم التسرع في الحكم (وز ارة التربية و التعليم، 2006، ب).

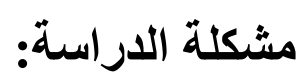

اعتبار اً من العام الدر اسي 1999/98 أدخلت وزارة التربية والتعليم نظام التعليم الأساسي، و اعتبر

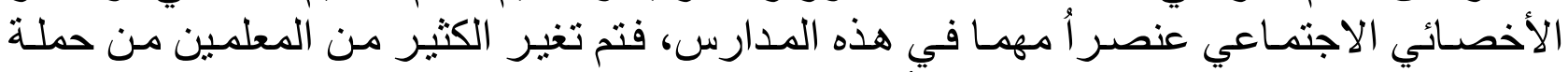

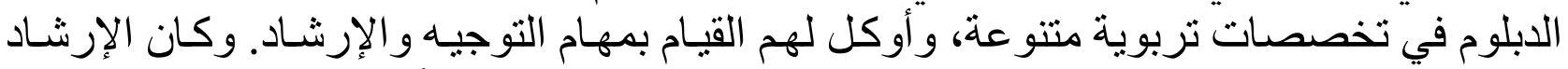

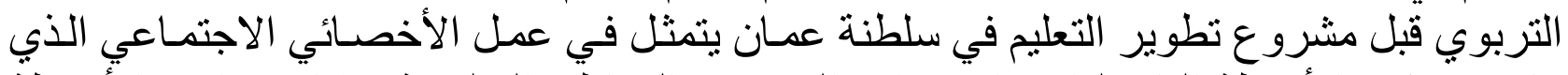

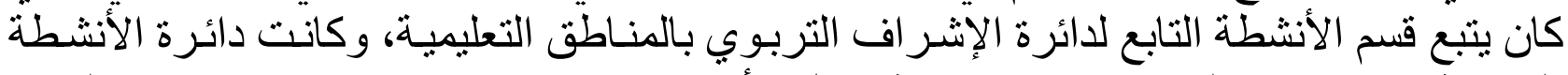

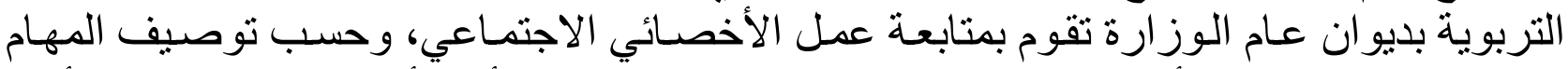

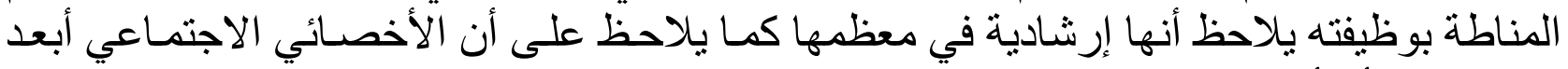

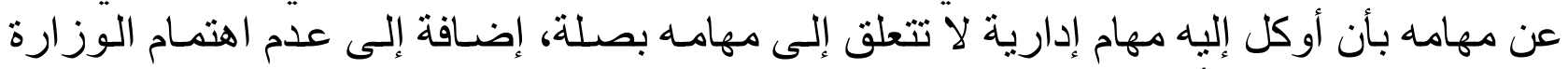

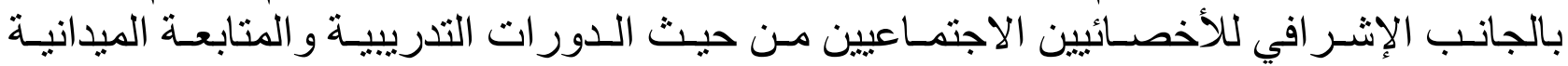

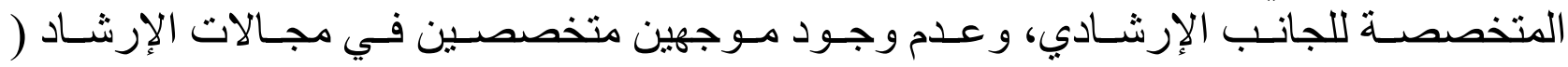

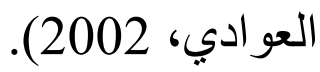

أنشارت الكثير من الدر اسات كدراسة العصفور (2004)، و النوفلي (2006)، و الثقصسي (2007)

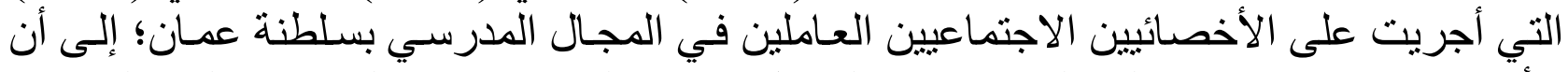

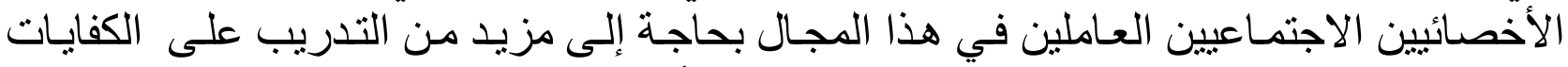
المهنية، وخاصة ما يتعلق منها بالجانب الإرشادي. فقد أكدت نتائج در اسة المعشني مزئ (2001) على 
أن القائمين على الإرشـاد و التوجيه يشتكون من ضـعف تـأهيلهم، وقلـة الوسـائل المتاحة لهم. فضـلا

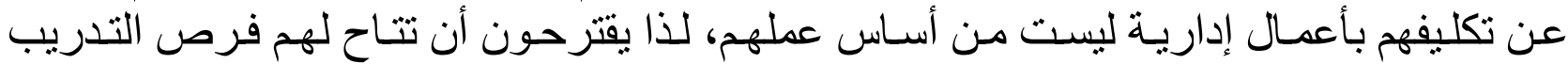

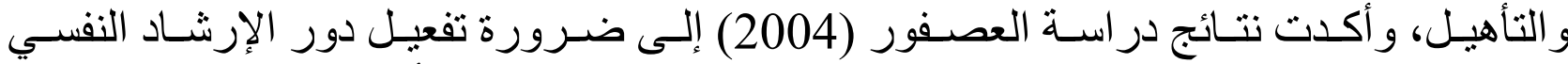

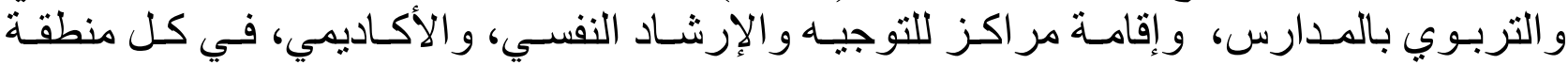
تعليمية، و هذا يتطلب التأهيل والتدريب في في هذا التخصص.

من خلال معايثة الباحث لو اقع عمل الأخصـائيين الاجتمـاعبين في المدارس؛ تبين أن هنـاك مهام

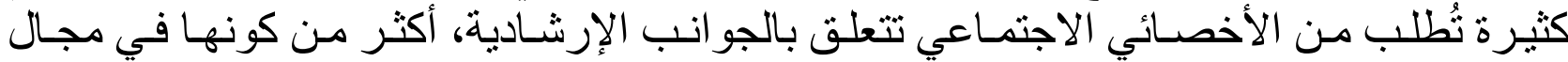

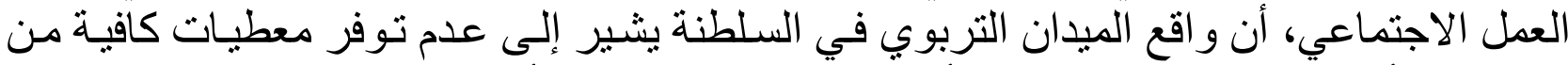

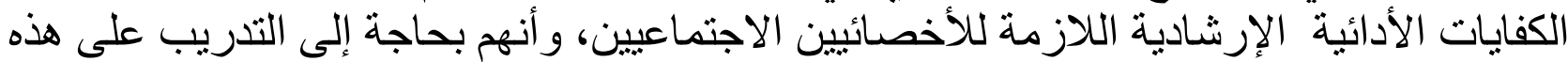

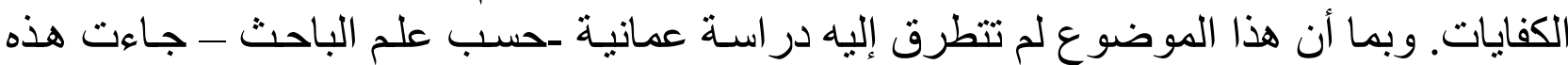

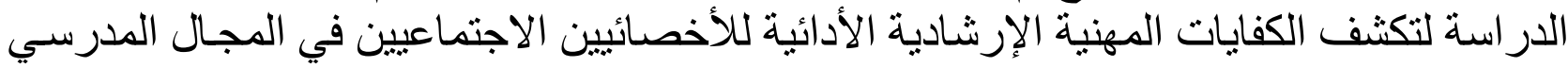

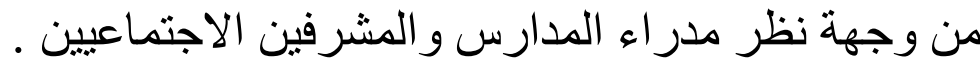
أهداف الدراسة:

الهدف الأول: تشخيص مستوى درجـة الكفايـات الإرشـادية الأدائية لدى الأخصسائيين الاجتمـاعيين من وجهة نظر مديري المدارس و المشرفين الاجتماعين.

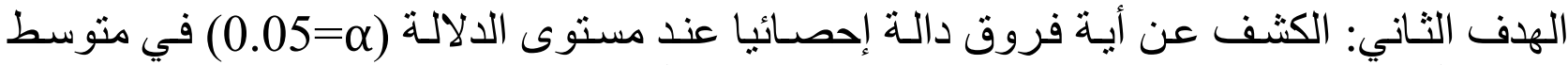
تمكن الأخصائيين الاجتماعيين في الكفايات الإرشادية الأدائية تعزى للمتغيراتينية دون الآتية: أ. متغير النوع الاجتماعي (ذكور ا/ إناثا). ب. متغنير المُقيّم (مدير مدرسة/ مشرف التربية الاجتماعية). ت. متغير المنطقة التعليمية (محافظة مسقط، منطقة جنوب الباطنة، المنطقة الداخلية). ث. متغير التخصص (دبلوم تربية، علم اجتماع، خدمة اجتماعية، تخصصسات أخرى). الار اسات السابقة:

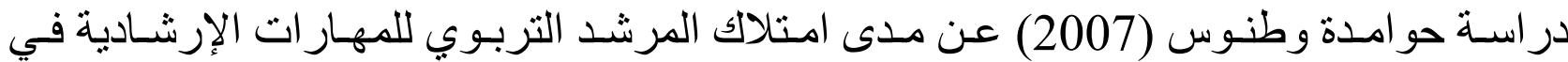

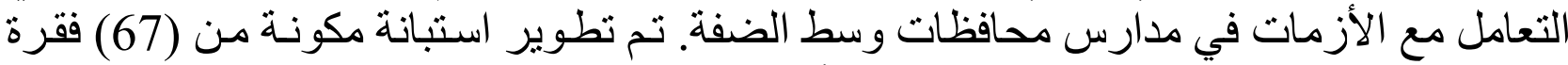
تعكس مهار ات المرشدين في التدخل وقت الأزمسات، وتم تطبيقها على عينـة مكونة من من (200)

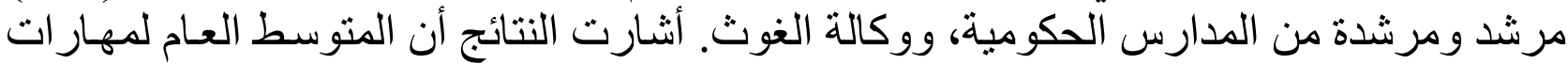

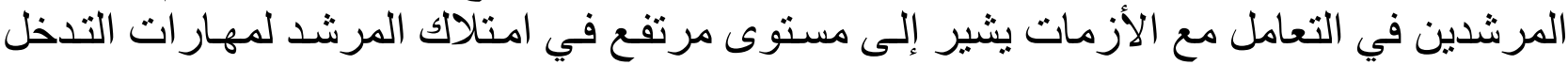

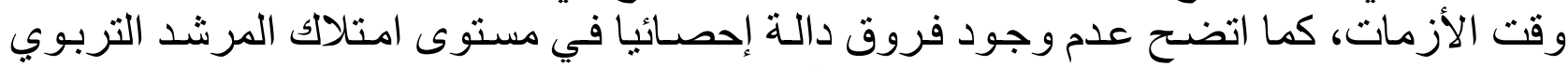

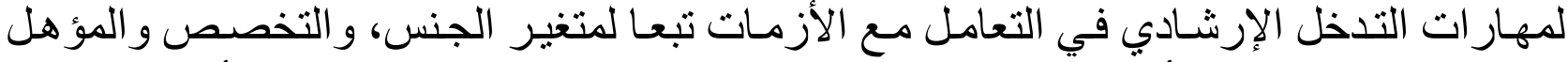
العلمي وسنو ات الخبرة. أوصت بإعطاء للمرشدين دور ا في مهار ات التدخل وقت الأزمات. أجرت الغساني (2007) دراسة بعنوان دور الأخصائي الاجتماعي في الحد من معوقات التعاون

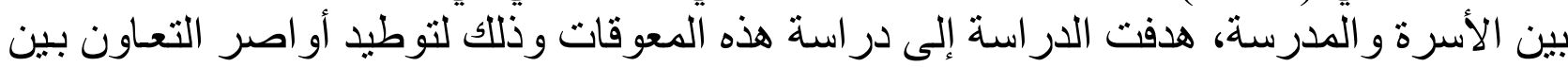

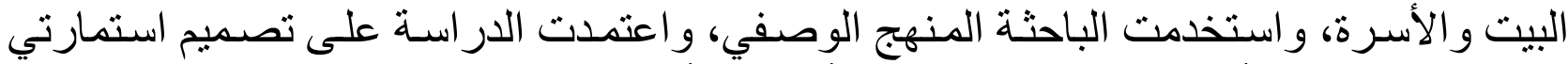
استبان ؛لكل مـن الأخصـائيين الاجتمـاعيين و أوليـاء الأمسور بالإضــافة إلى دليـل المقابلـة لمـديري 
المـدارس وكـان مـن أهـم النتائج دفـاع الأخصـائي الاجتمـاعي عن مصـلحة أوليـاء الأمسور حيـث

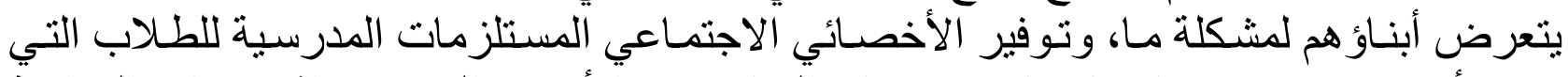

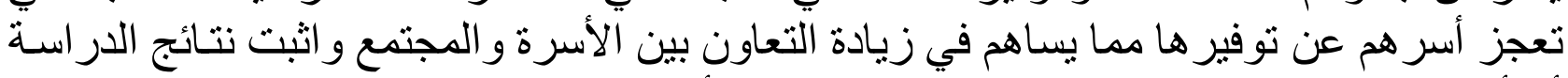

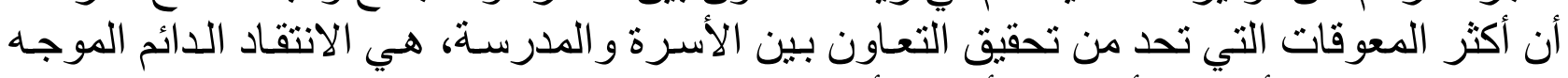

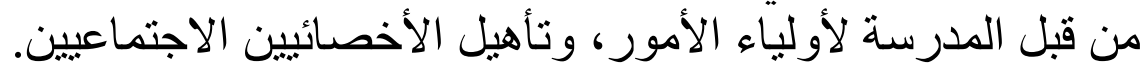

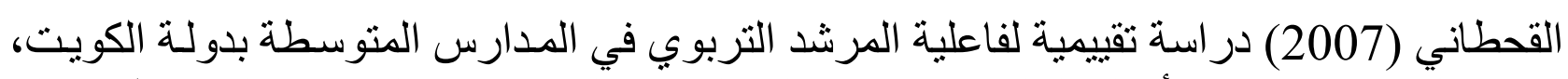

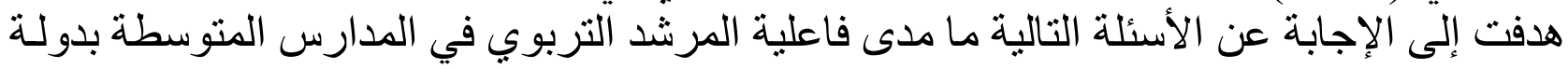

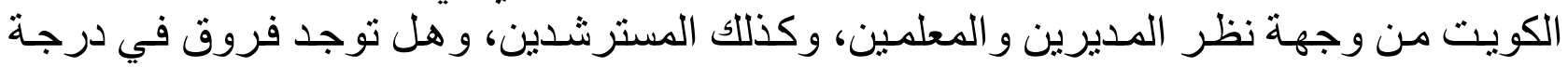

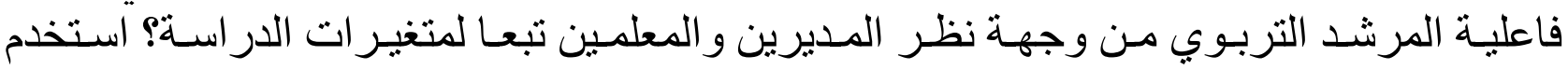

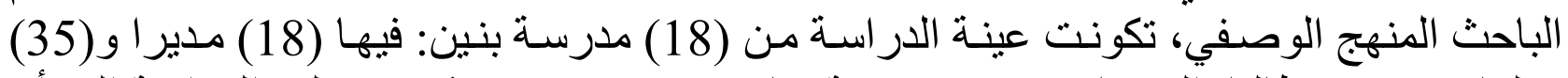

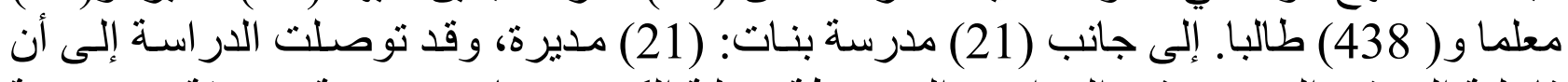

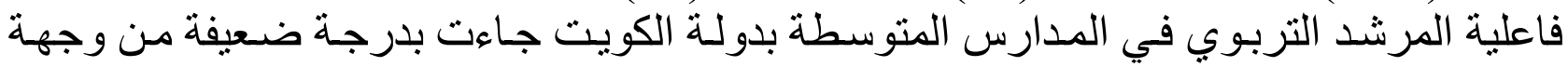

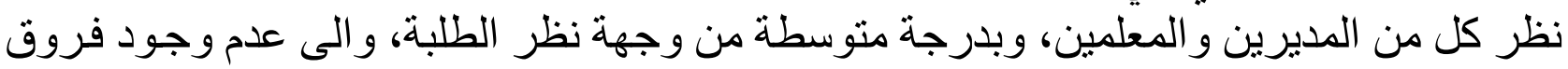

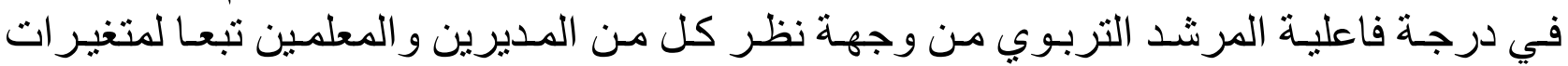

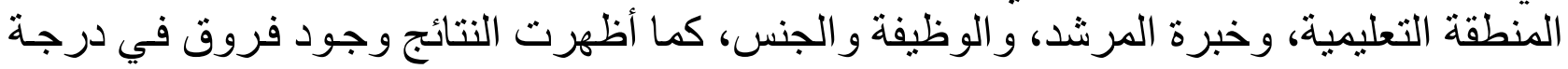

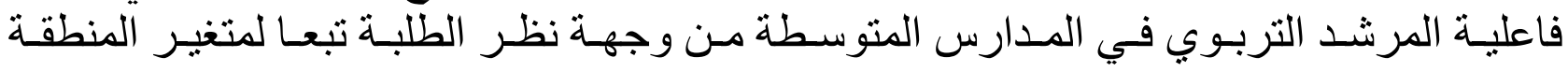
التعليمية.

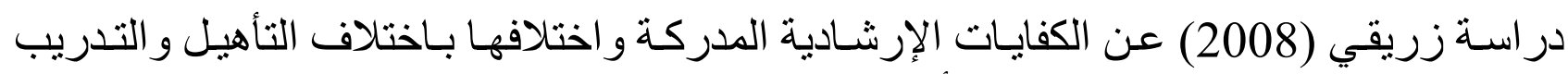

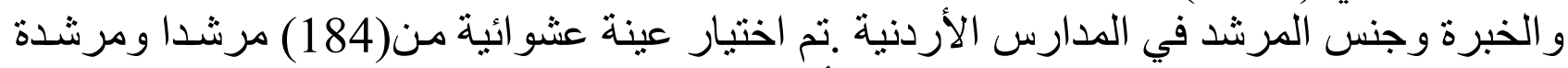

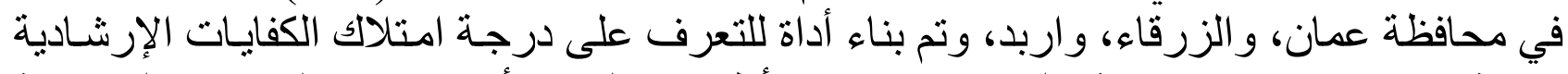

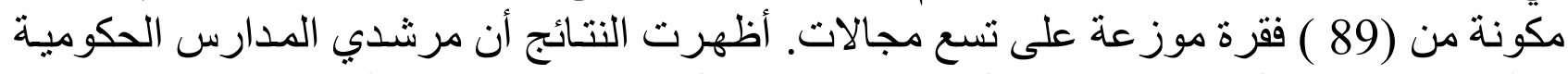

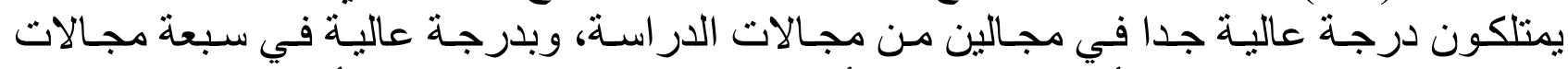

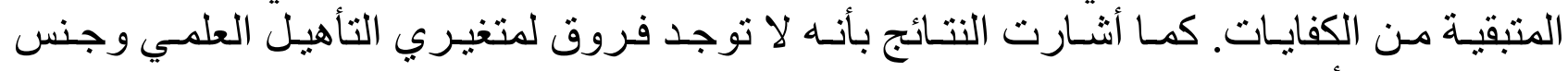

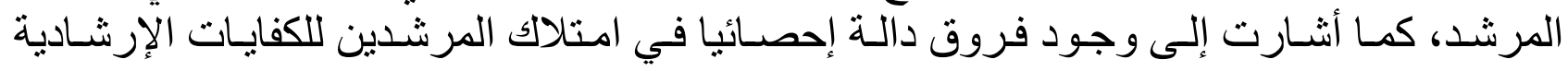
المدركة ترجع لمتغير الخبرة. منهج الارلة اسلة:

اتبع الباحث المنهج الوصفي الذي بعتمد على وصف الظاهرة كما توجد في الواقع، و التعبير عتها

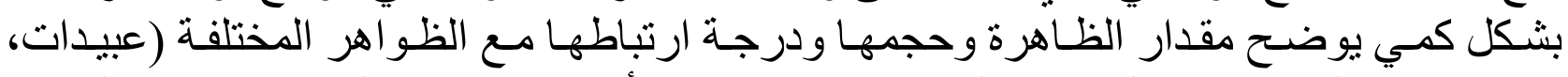

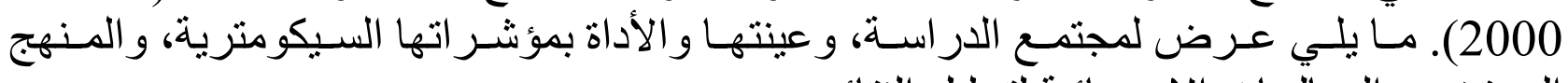
المستخدم و المعالجات الإحصائية لتحليل النتائج.

مجتمع الدراسة:

تكون مجتمـع الدر اسـة مـن مـديري مـدارس محافظـة مسـقط، ومنطقة الباطنـة جنـوب، و المنطقة

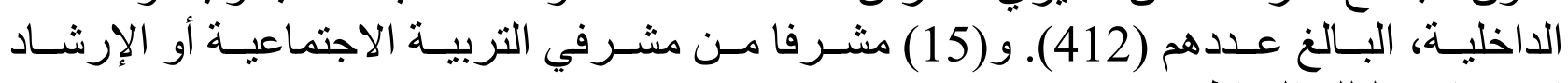
الاجتماعي لتلك المناطق. عينة الدراسة: 


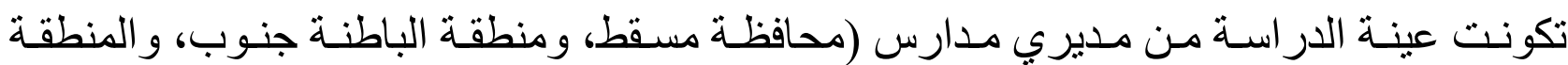

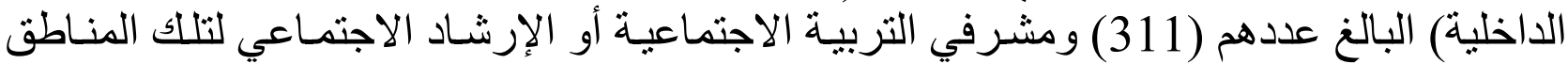

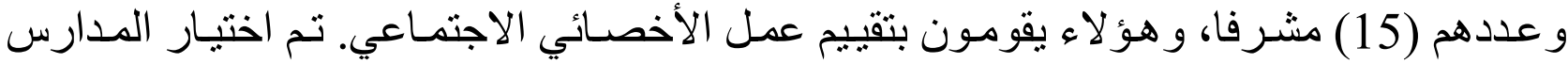
بالطريقة العثو ائية في كل منطقة تعليمية.

أداة الدراسة:

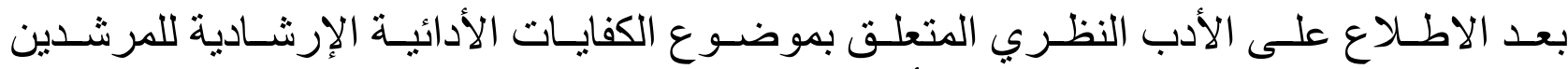

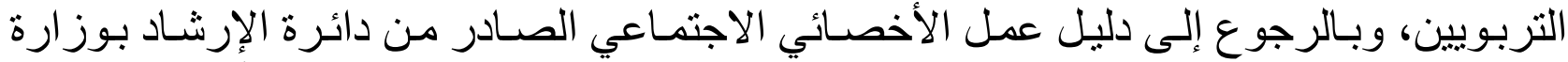

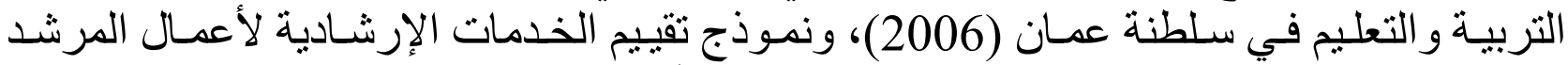

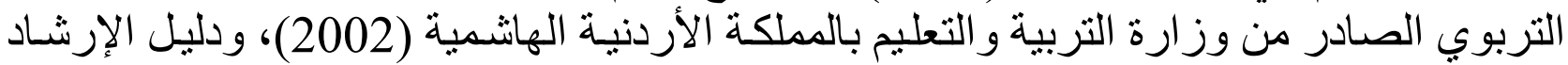
النفسي والاجتماعي الصادر من مملكة البحرين (2003)؛ طور الباحث استبانة الكفايـات الأدائية

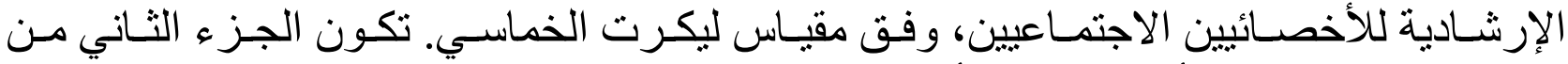

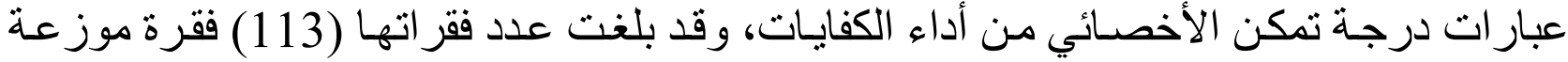
على تسع مجالات.

صدق الأداة وثباتهها: بعد الانتهاء من إعداد الأداة في صورتها المبدئية، في ضدوء الإطسار النظري و الدر اسـات السـابقة؛

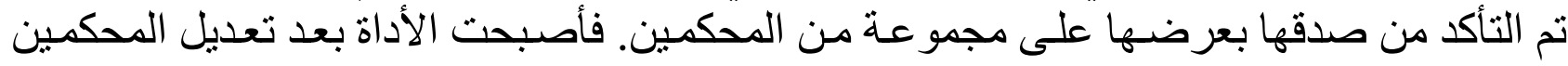
مكونة من المجالات التالية:

- الخطة الإرشادية: تتكون من (9) فقر ات. ويشمل الفقر ات (1 - 9). - الإرشاد الفردي ومهارته: يتكون من (13) فقرة، تبدأ من (10- 22). - الإرشاد الجمعي: يتكون من (9) فقرات، ويشمل الفر ات(31-23). ـ الاتصسال و التو اصل و العلاقات الخارجية: بتكون من (12) فقرة، تشتمل الفقرات (32-43) - السمات الشخصية: يتكون من (9) فقر ات، من الفقرة (44- 52). - ـ التوجيه الجمعي: يتكون من(8) فقرات. يشتمل على الفقرات (53- 60). - التسجيل و التوثيق: يتكون من(8) فقر ات، ويشتمل على الفقرات (61-68). أمسا ثبـات الأداة (Reliability): فبعد التأكد من صدق الأداة، تم تطبيقها على (50) مدير او مشـرفا للتربية الاجتماعيـة، لحسـاب معامل ثبـات الأداة عن طريت معامل الاتسـاق الداخلي ألفا كرونباخ

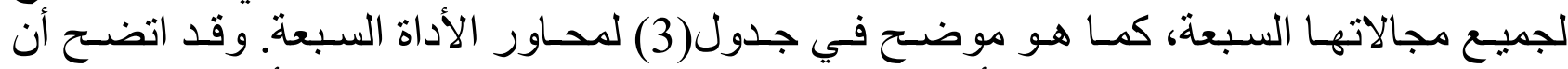
معاملات الاتساق الداخلي لمحاور الأداة الرئيسية تراوحت بين (3) (0.93-0.80 ) وأن معامل الثبـات الكلي لفقر ات الأداة ككل بلغت قيمته (0.98) وهي قيمة تدل على أن الأداة صالحة لجمـع مـا أعدت من أجله.

\section{المعالجات الإحصائية:}

للإجابــة عـن السـؤ ال الأول: اسـتخدم الباحـث التحليـل الوصـفي، لبيـان المتوســات الحسـابية و الانحر افات المعيارية لكل مجال من مجالات الأول الأداة والأداة ككل. 


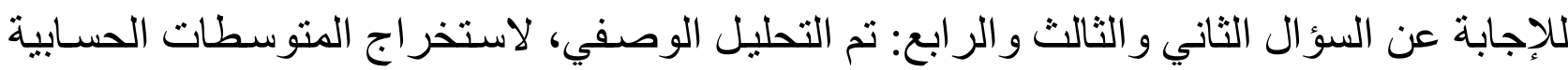

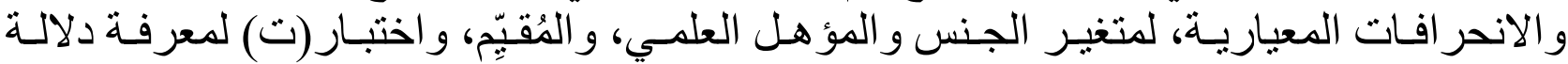

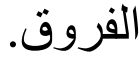

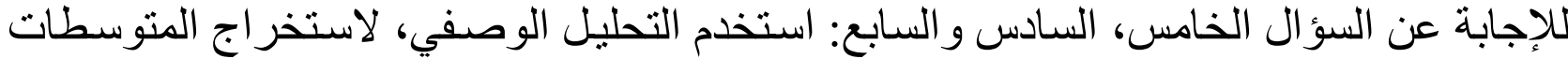

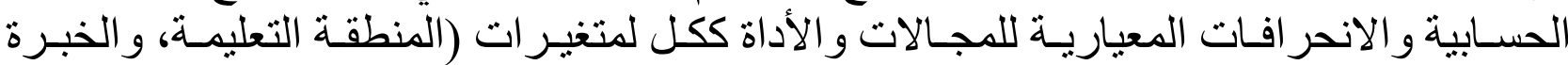

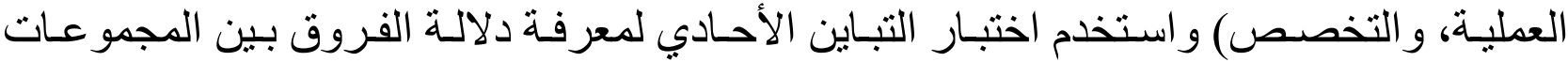

وداخلها.

عرض النتائج:: - ان أولا: النتائج المتعلقة بالسؤال الأول:

للإجابة عن السؤال الأول: الذي ينص على: "مـا مستوى درجـة الكفايـات الإرشـادية الأدائية لدى الإقى

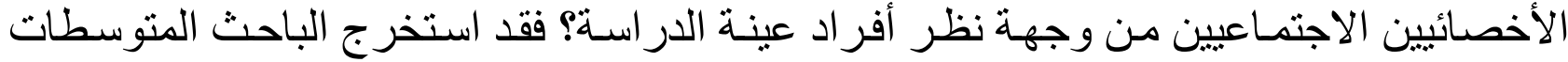

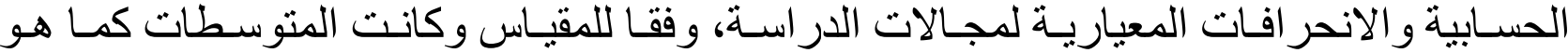
موضح في الجدول الآتي:

الجدول (1) المتوسطات الحسابية و الانحر افات المعيارية لمجالات الدر اسة مرتبة تنازليا حسب المتوسطات

\begin{tabular}{|c|c|c|c|c|c|}
\hline الكفاية & 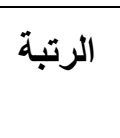 & المعياري & الحستوبي & 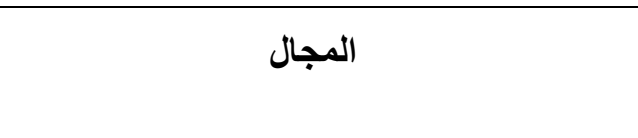 & رالمجال \\
\hline عالية الية & 1 & 0.62 & 3.82 & مجال السمات الثخصية. & -5 \\
\hline عالبة & 2 & 0.58 & 3.75 & مجال الاتصال و التو اصل و العلاقات الخارجية. & -4 \\
\hline عالية & 3 & 0.61 & 3.674 & مجال التوجيه الجمعي. & -6 \\
\hline عالية & 4 & 0.65 & 3.673 & مجال التوثيق و التنجيل. & -7 \\
\hline متوسطة ل & 5 & 0.56 & 3.664 & مجال الإرشاد الفردي ومهار اته. & -2 \\
\hline 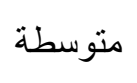 & 6 & 0.59 & 3.662 & مجال الخطة الإرشادية. & -1 \\
\hline 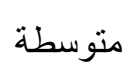 & 7 & 0.67 & 3.660 & مجال الإرشاد الجمعي. & -3 \\
\hline عالية & & 0.53 & 3.70 & الارجة الكلية. & \\
\hline
\end{tabular}

يتضـح مدىى تـوفر الكفايـات الأدائيسة الإرشـادية مـن الجدول أعـلاه، لـدى عينـة مـن الأخصـائيين

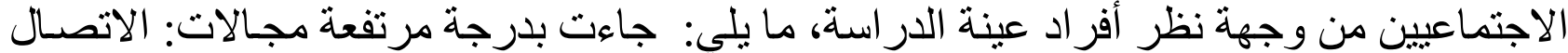

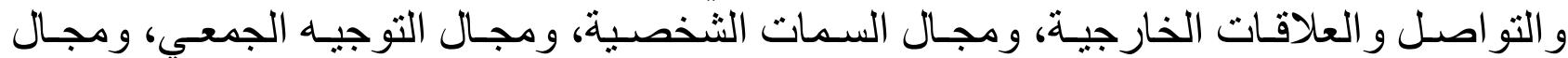

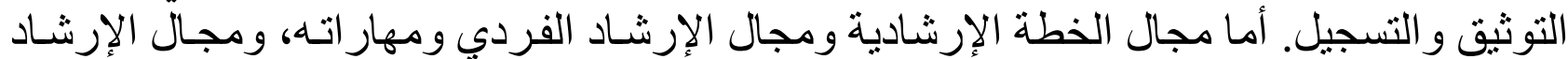
الجمعي فقد كانت درجة نوفر الكفايات فيه بدرجة منوسة الأنة جاء مجال السمات الثخصية في المرتبة الأولى بمتوسط حسابي (3.82) وبانحر اف معياري قدره 


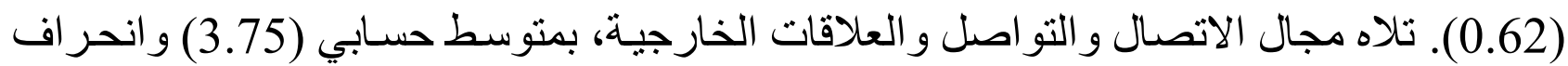

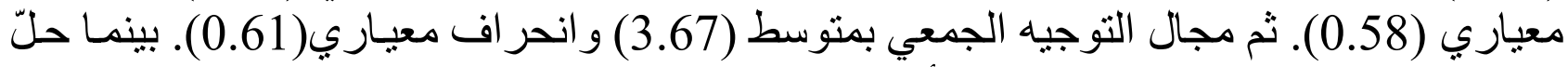

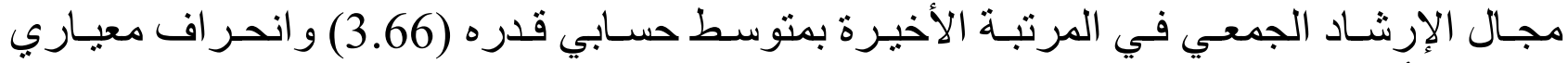
(0.67). أما معدل المتوسط الحسابي الكلي لجميع المجالات فبلّغ (3.70) وبانحر افت معياري قدره

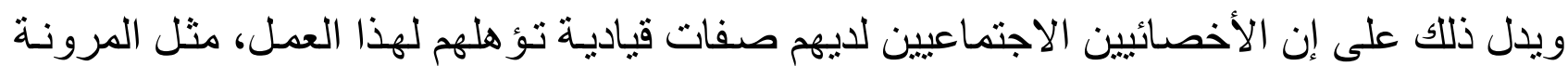

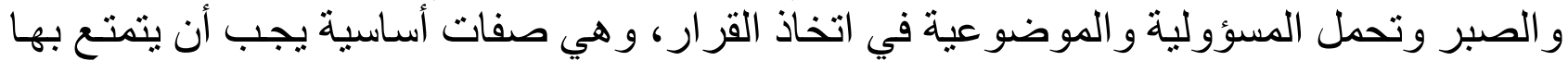

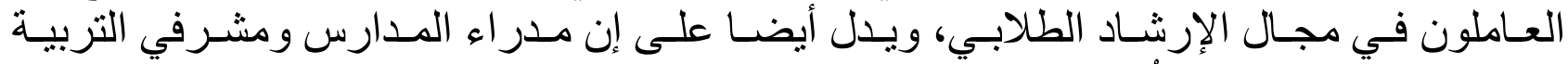

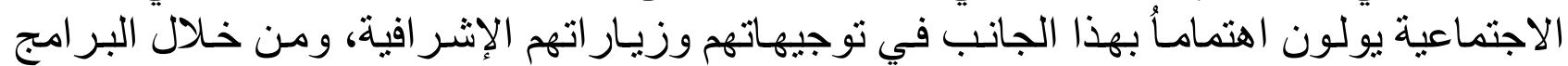

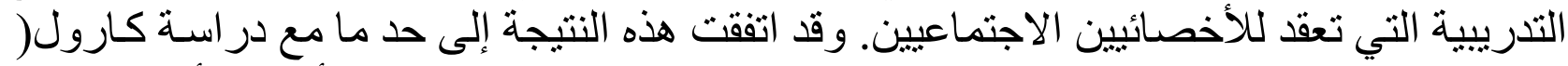

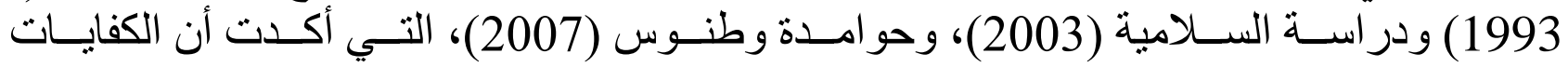

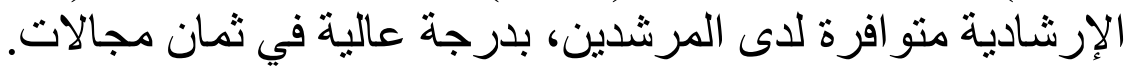

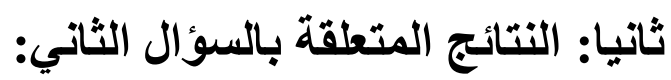

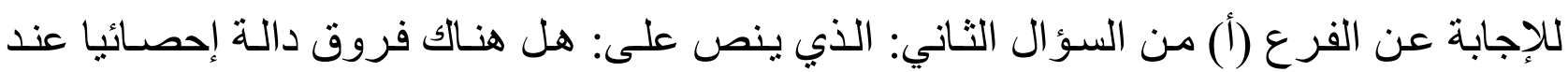

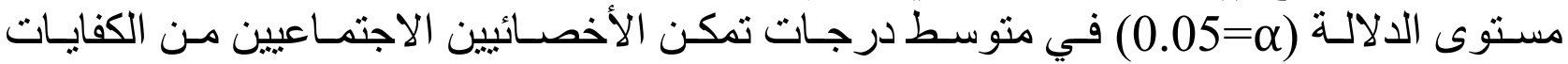

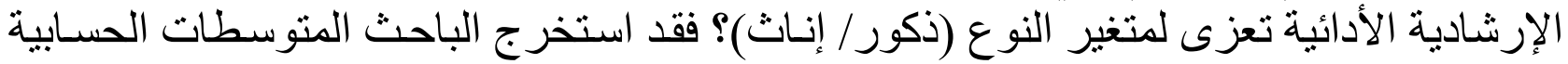

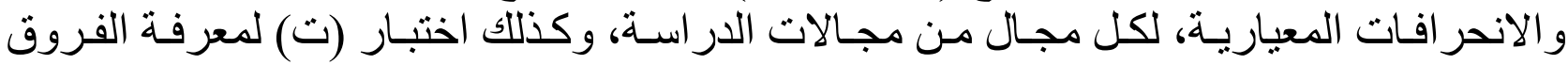
الفردية ودلالاتها بين متغيرين.

الجدول (2) المتوسطات الحسابية والانحر افات المعيارية لمجالات الدراسة حسب متغير النوع

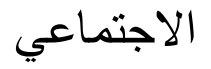

\begin{tabular}{|c|c|c|c|c|c|c|}
\hline \multirow{3}{*}{ الدلالة الدتوى } & \multirow{3}{*}{ قات } & \multicolumn{2}{|c|}{ الانحر اف المعياري } & \multicolumn{2}{|c|}{ المتوسط الحسابي } & \multirow{3}{*}{ 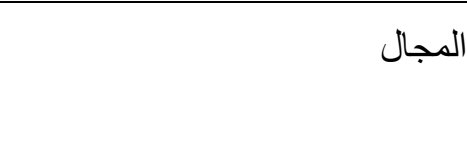 } \\
\hline & & إناث & ذكور & إناتث & ذكور & \\
\hline & & ن & ن=104 & ن=207 & ن=104 & \\
\hline 0.03 & *2.12 & .55 & .67 & 3.71 & 3.55 & مجال الخطة الإرشادية \\
\hline 0.03 & ${ }^{*} 2.10$ & .54 & .60 & 3.71 & 3.56 & مجال الإرشاد الفردي ومهار اته \\
\hline 0.00 & ${ }^{\star} 2.78$ & .68 & .63 & 3.73 & 3.51 & مجال الإرشاد الجمعيى \\
\hline 0.00 & *2.85 & .55 & .62 & 3.81 & 3.62 & 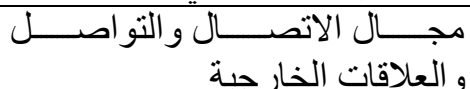 \\
\hline 0.01 & *2.47 & .58 & .68 & 3.89 & 3.69 & مجال السمات الثخصية \\
\hline 0.00 & *3.40 & .55 & .68 & 3.76 & 3.50 & مجال التوجيه الجمعي \\
\hline 0.04 & *2.06 & .59 & .75 & 3.72 & 3.55 & مجال التوثيق والتسجيل \\
\hline 0.00 & *2.99 & .51 & .56 & 3.76 & 3.57 & الدرجة الكلية \\
\hline
\end{tabular}

* د دالة عند مستوى( 0.05).

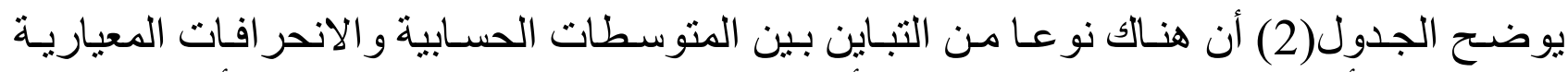

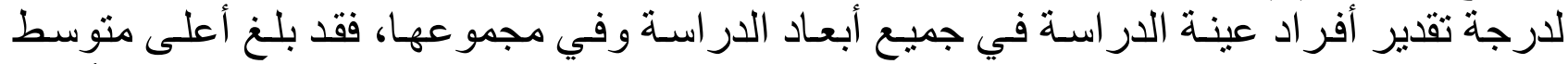

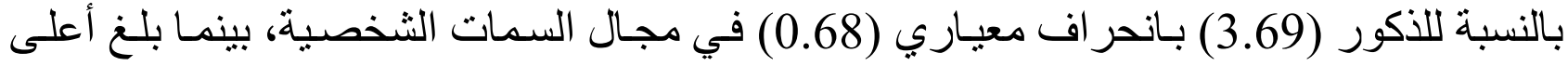

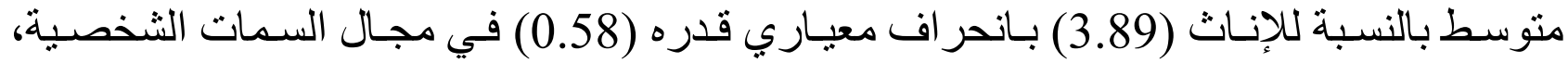
و أثنارت نتائج اختبار (ت) بأنه توجد فروق دالة إحصائيا عند مسنتوى دلالة (0. 


\section{المجالات وفي مجمو عها لصالح الإناث.}

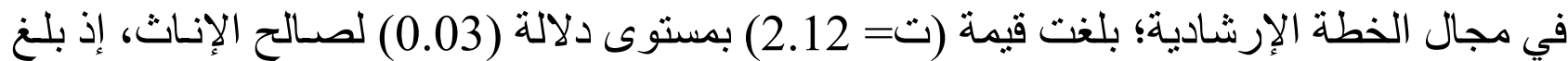

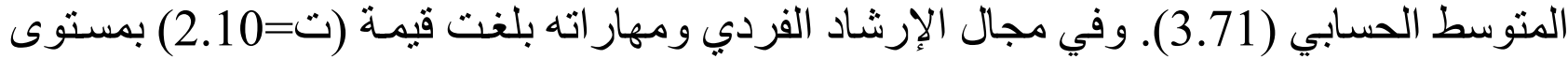

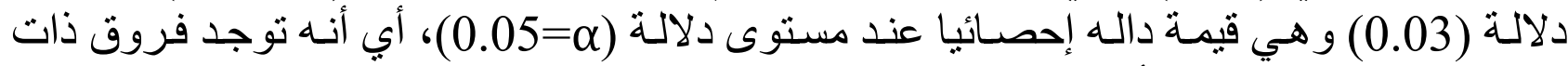

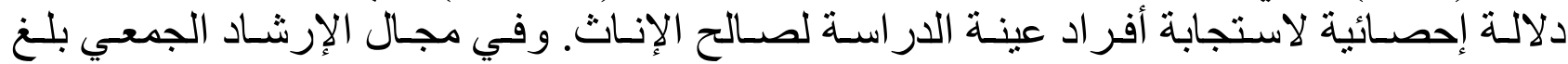

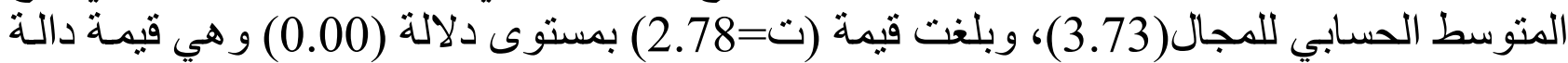

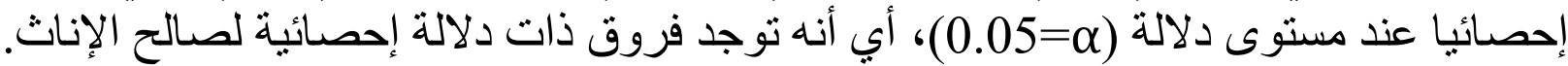

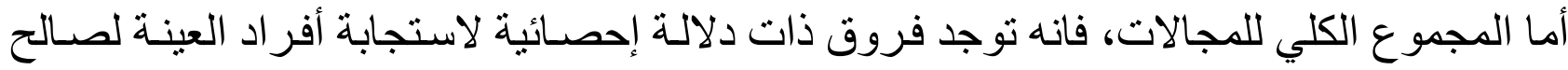

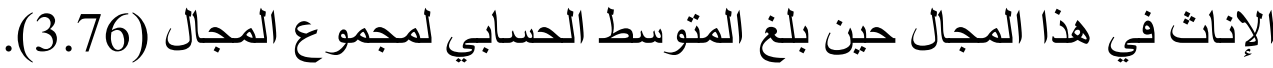
للإجابة عن (ب) من السؤال الثاني:

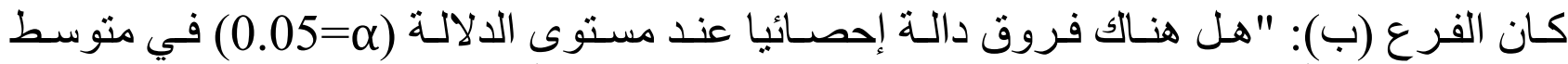

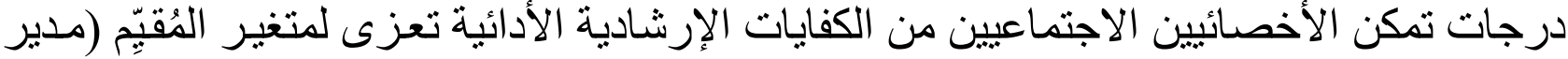

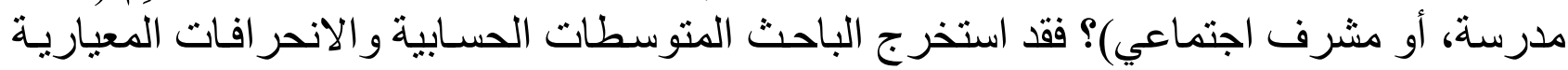

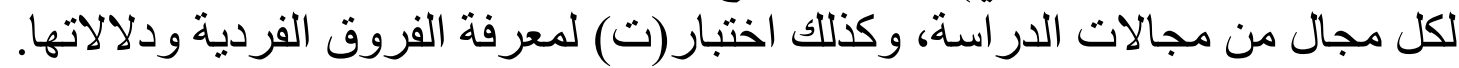
الجدول (3) المتوسطات الحسابية والانحر افات المعيارية لمجالات الدر اسة وفقاً لتقدير أفر اد العينة

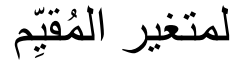

\begin{tabular}{|c|c|c|c|c|c|c|}
\hline \multirow{2}{*}{ مستوى } & \multirow{2}{*}{ قيمة } & \multicolumn{2}{|c|}{ مشرف تربية اجتماعية } & \multicolumn{2}{|c|}{ مدير مدرسة } & \multirow[t]{2}{*}{ 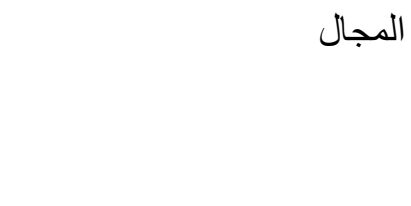 } \\
\hline & & المعياري الاف & المسابي & الانحر اف المعياري & المسابي & \\
\hline 0.31 & 1.00 & .56 & 3.63 & .64 & 3.70 & مجال الخطة الإرشـادية \\
\hline 0.00 & *2.69 & .55 & 3.59 & .58 & 3.76 & 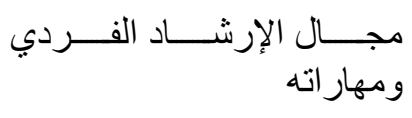 \\
\hline 0.10 & 1.64 & .69 & 3.60 & .65 & 3.73 & مجال الإرشاد الجمعي \\
\hline 0.12 & 1.53 & .56 & 3.71 & .60 & 3.81 & 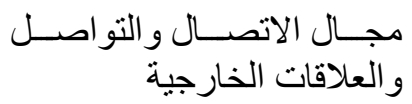 \\
\hline 0.00 & $* 3.75$ & .59 & 3.71 & .64 & 3.98 & مجال السمات الشخصية \\
\hline 0.83 & .207 & .54 & 3.66 & .69 & 3.68 & مجال التوجيه الجمعي \\
\hline 0.02 & *2.31 & .60 & 3.59 & .72 & 3.77 & مجال التوثيق و التسجيل \\
\hline 0.02 & *2.20 & .57 & 3.78 & .57 & 3.78 & الدرجة الكلية \\
\hline
\end{tabular}

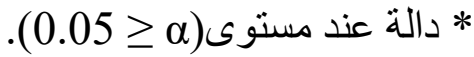

يوضح الجدول (3) أن هناك تباينا بين المتوسطات الحسـابية و الانحر افات المعياريـة لدرجة تقدير 


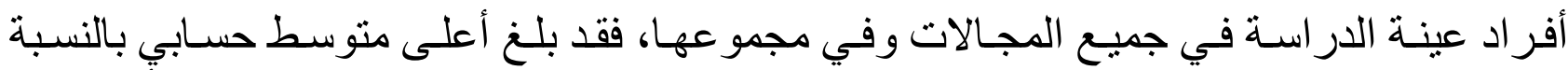

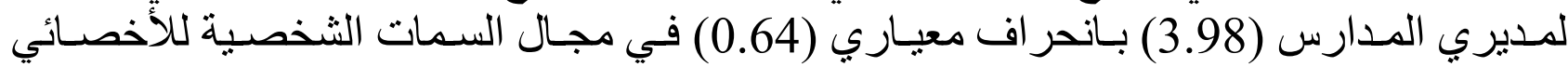

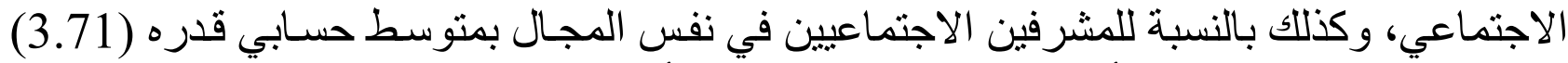

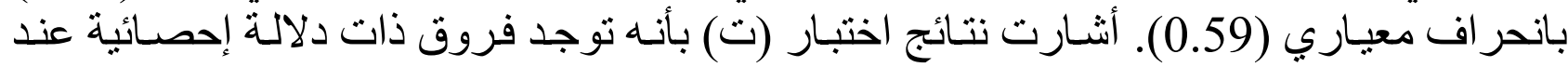

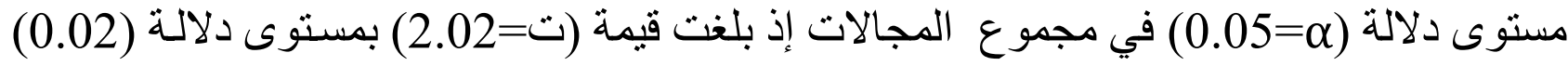

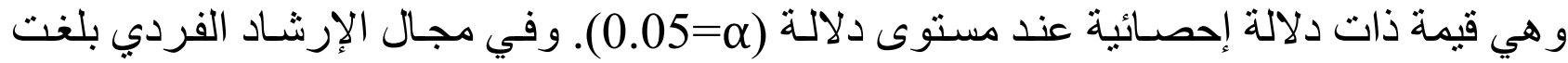

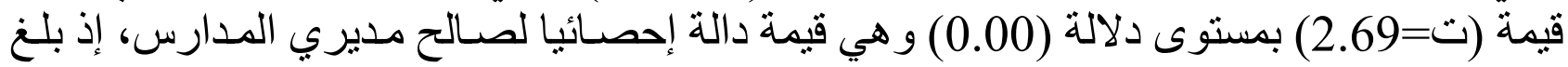

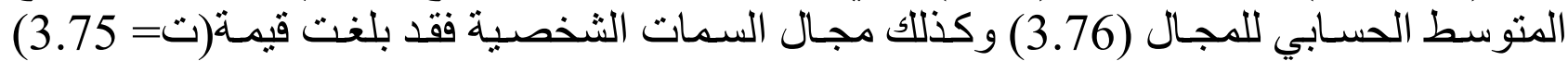

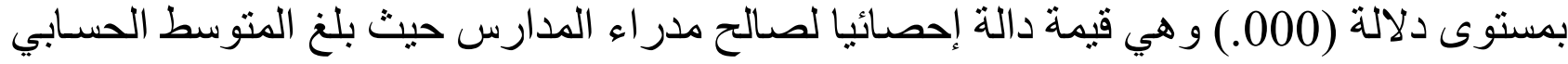

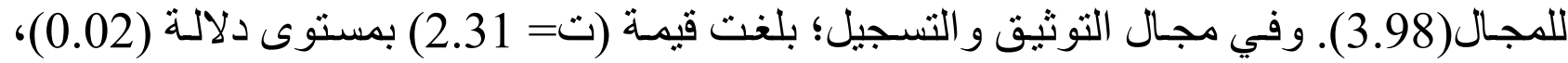

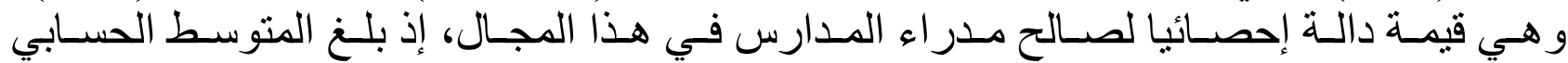

\section{للإجابة عن (ت) من السؤال الثاني:}

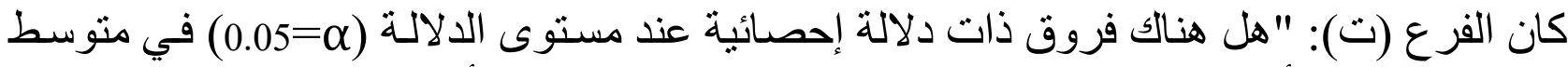

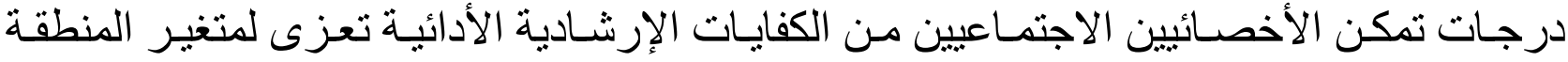

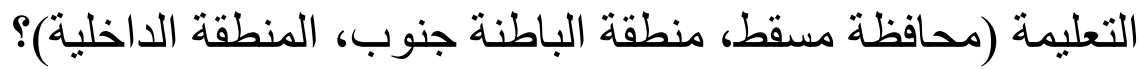

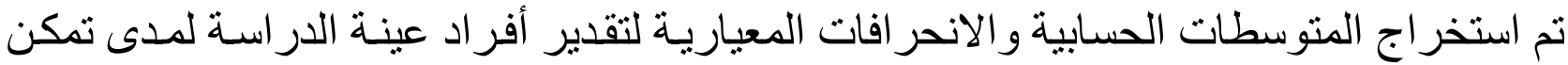

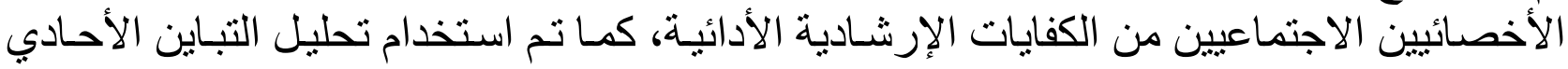

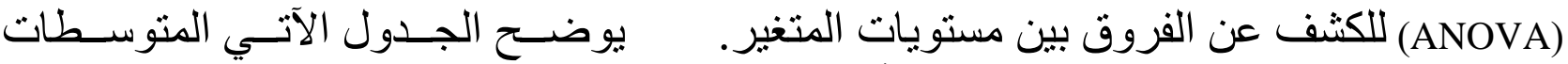

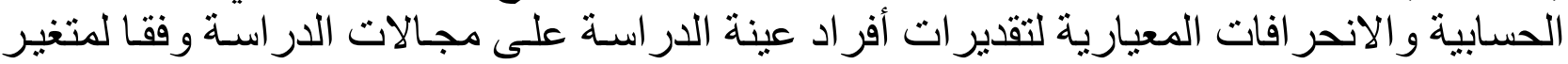

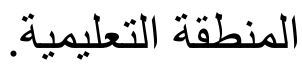

الجدول (4) المتوسطات الحسابية و الانحر افات المعيارية لمجالات الدر اسة لمتغير المنطقة التعليمية العيات الحيات

\begin{tabular}{|c|c|c|c|c|c|c|}
\hline \multicolumn{6}{|c|}{ المناطق التعليمية } & \multirow{3}{*}{ المجالات } \\
\hline \multicolumn{2}{|c|}{ 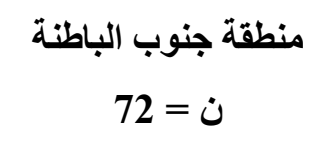 } & \multicolumn{2}{|c|}{ المنطقة الداخلية } & \multicolumn{2}{|c|}{ محافظة مسقط = 109} & \\
\hline المعياري & الحستبط & الانحراف & المستوسط & المعياري & المستوسط & \\
\hline 0.56 & 3.76 & 0.60 & 3.57 & 0.59 & 3.69 & الخطة الإرشـادية \\
\hline 0.53 & 3.67 & 0.57 & 3.57 & 0.57 & 3.75 & الإرشاد الفردي ومهار اته \\
\hline 0.73 & 3.76 & 0.68 & 3.51 & 0.60 & 3.76 & الإرشاد الجمعي \\
\hline 0.55 & 3.79 & 0.61 & 3.68 & 0.56 & 3.79 & الاتصـال و العلاقات الخارجية \\
\hline
\end{tabular}


IJASOS- International E-Journal of Advances in Social Sciences, Vol. VI, Issue 16, April 2020

\begin{tabular}{|c|c|c|c|c|c|c|}
\hline 0.55 & 3.89 & 0.65 & 3.76 & 0.63 & 3.85 & السمات الشخصية \\
\hline 0.56 & 3.78 & 0.62 & 3.58 & 0.60 & 3.70 & التوجيه الجمعي \\
\hline 0.63 & 3.73 & 0.60 & 3.64 & 0.73 & 3.65 & التوثيق و التسجيل \\
\hline 0.48 & 3.76 & 0.53 & 3.62 & 0.55 & 3.75 & مجموع المجالات \\
\hline
\end{tabular}

وللكثف عما إذا كانت الفروق المشاهدة بين المتوسطات على المجـالات ذات دلالة إحصـائية عند

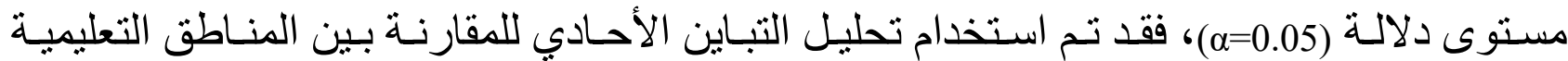
الثلاث( محافظة مسقط، و المنطقة الداخلية، ومنطقة جنوب الباطنة) في كل مجـال من المجالات. كما في الجدول الاتي.

الجدول (5) تحليل التباين الأحادي (ANOVA) لتقديرات العينة لمجالات الدر اسة وفقا لمتغير المنطقة التعلبمبة لفية

\begin{tabular}{|c|c|c|c|c|c|c|}
\hline مســتلةى & 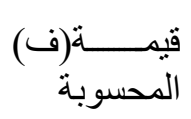 & متوسعــــــ & درجـــات & 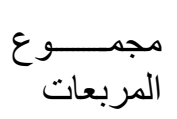 & مصدر التباين & المجالات \\
\hline \multirow{2}{*}{0.07} & \multirow{2}{*}{2.61} & 0.93 & 2 & 1.86 & بين المجمو عات & \multirow{2}{*}{ الخطة الإرشـادية } \\
\hline & & 0.35 & 308 & 109.70 & داخل المجمو عات & \\
\hline \multirow{2}{*}{0.04} & \multirow{2}{*}{$* 3.04$} & 0.97 & 2 & 1.94 & بين المجمو عات & \multirow{2}{*}{ الإرشاد الفردي } \\
\hline & & 0.32 & 308 & 98.50 & داخل المجمو عات & \\
\hline \multirow{2}{*}{0.00} & \multirow{2}{*}{$* 4.92$} & 2.21 & 2 & 4.43 & بين المجمو عات & \multirow{2}{*}{ الإرشاد الجمعي } \\
\hline & & 0.45 & 308 & 138.65 & داخل المجمو عات & \\
\hline \multirow{2}{*}{0.25} & \multirow{2}{*}{1.35} & 0.46 & 2 & 0.92 & بين المجمو عات & \multirow{2}{*}{ 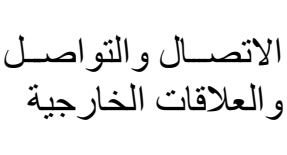 } \\
\hline & & 0.34 & 308 & 104.64 & داخل المجمو عات & \\
\hline \multirow{2}{*}{0.32} & \multirow{2}{*}{1.13} & 0.44 & 2 & 0.89 & بين المجمو عات & \multirow{2}{*}{ السمات الشخصية } \\
\hline & & 0.39 & 308 & 121.45 & داخل المجمو عات & \\
\hline \multirow{2}{*}{0.07} & \multirow{2}{*}{2.60} & 0.96 & 2 & 1.92 & بين المجمو عات & \multirow{2}{*}{ التوجيه الجمعي } \\
\hline & & 0.36 & 308 & 113.55 & داخل المجمو عات & \\
\hline \multirow{2}{*}{0.60} & \multirow{2}{*}{0.49} & 0.21 & 2 & 0.43 & بين المجمو عات & \multirow{2}{*}{ التوثيق و التسجيل } \\
\hline & & 0.43 & 308 & 134.30 & داخل المجمو عات & \\
\hline \multirow[t]{2}{*}{0.08} & \multirow[t]{2}{*}{2.49} & 0.71 & 2 & 1.42 & بين المجمو عات & \multirow[t]{2}{*}{ مجموع المجالات } \\
\hline & & 0.28 & 308 & 87.87 & داخل المجمو عات & \\
\hline
\end{tabular}




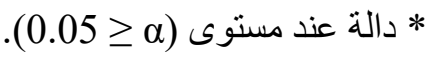

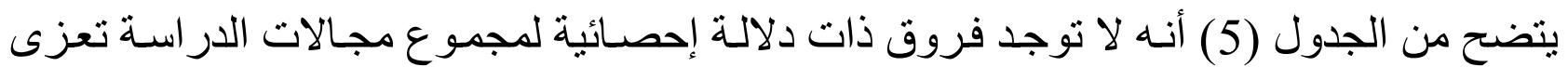

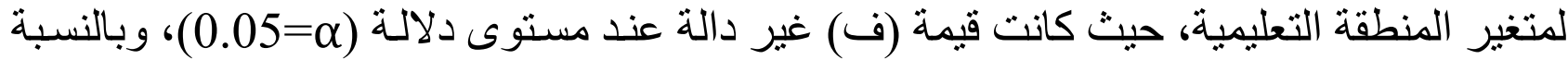
للمجالات فإنه توجد فروق ذات دلالة إحصائية في مجال الإرشاد الفردي ومجـال الإرشـاد الجمعي فئهي

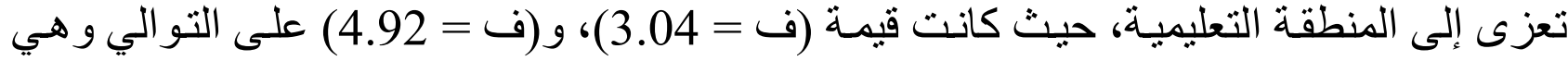

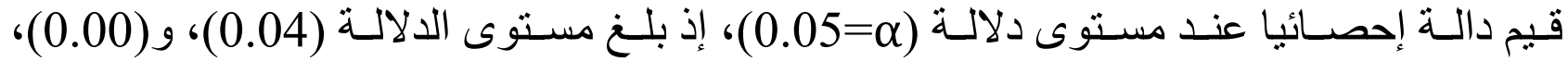

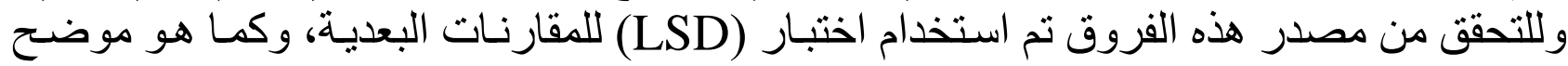

في جدول (6).

الجدول (6) اختبار (LSD) للمقارنات البعدية للفروق بين المناطق التعليمية في مجال الإرشاد الفردي، و الإرشاد الجمديه

\begin{tabular}{|c|c|c|c|c|c|c|}
\hline \multicolumn{3}{|c|}{ المناطق } & \multirow[t]{2}{*}{ المتوسط } & \multirow[t]{2}{*}{ ن } & \multirow[b]{2}{*}{ المنطقة } & \multirow{2}{*}{$\overline{3}$} \\
\hline \multirow{5}{*}{ الباطنة } & الاخلية & مسقط & & & & \\
\hline & $* 0.18$ & & 3.75 & 109 & محافظة مسقط & \multirow{3}{*}{ 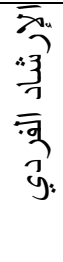 } \\
\hline & & $* 0.18$ & 3.57 & 130 & المنطقة الداخلية & \\
\hline & & & 3.67 & 72 & منطقة جنوب الباطنة & \\
\hline & $* 0.24$ & & 3.76 & 109 & محافظة مسقط & \multirow{3}{*}{$\begin{array}{l}\overline{\bar{x}_{1}} \\
07 \\
7 \\
7\end{array}$} \\
\hline \multirow[t]{2}{*}{$* 0.24$} & & $* 0.24$ & 3.51 & 130 & المنطقة الداخلية & \\
\hline & $* 0.24$ & & 3.76 & 72 & منطقة جنوب الباطنة & \\
\hline
\end{tabular}

* مصدر الفروق، دالة عند مستوى (0.05 ( 0.05

يكثف الجدول (6) عن وجود فروق لصالح محافظة مسقط مقابـل المنطقة الداخليـة في مجـال

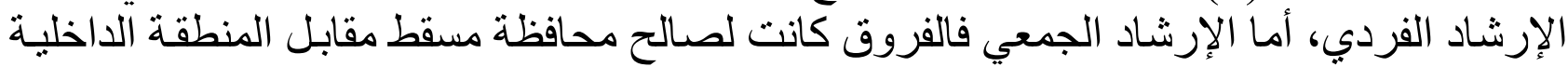
ولصالح منطقة جنوب الباطنة مقابل المنطقة الإدياد الداخلية. للإجابة عن (ث) من السؤال الثاني:

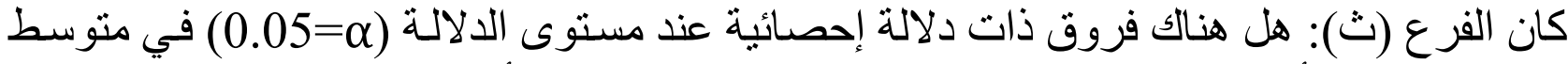

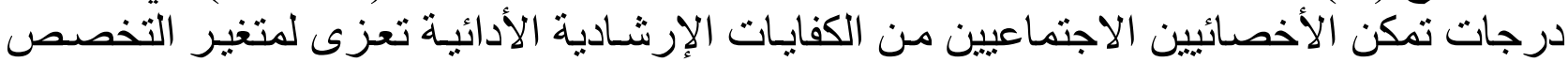

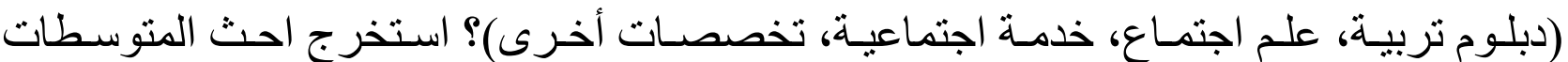

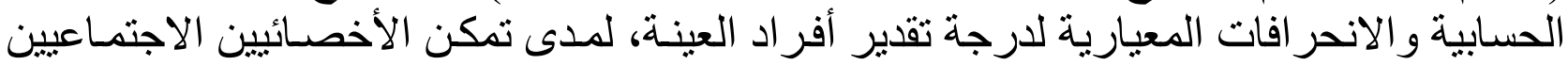

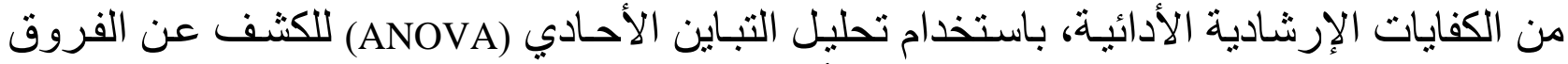

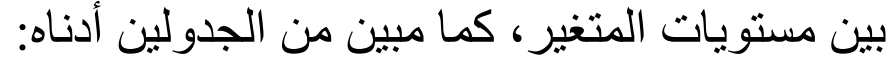

الجدول (7) المتوسطات الحسابية و الانحر افات المعيارية لمجالات الدر اسة لتقدير أفر اد العينة لمتغير التخصص 
IJASOS- International E-Journal of Advances in Social Sciences, Vol. VI, Issue 16, April 2020

\begin{tabular}{|c|c|c|c|c|c|c|c|c|}
\hline \multicolumn{2}{|c|}{ تخصصات أخرى } & \multicolumn{2}{|c|}{ خدمة اجتماعية } & \multicolumn{2}{|c|}{ نلم اجتماع } & \multicolumn{2}{|c|}{ ندبلوم تربية } & \multirow[t]{2}{*}{ المجال } \\
\hline المعياري & الحستوسط & الالمعراف & الحستوسط & الانحراف & المستوسط & الانحراف & الحستبط & \\
\hline .61 & 3.58 & .50 & 3.61 & .62 & 3.69 & .64 & 3.61 & مجــــــال الخطـــــــة \\
\hline .57 & 3.64 & .55 & 3.60 & .56 & 3.71 & .63 & 3.50 & الفردي ومـهار الإرشـــــاد \\
\hline .96 & 3.74 & .57 & 3.61 & .63 & 3.70 & .71 & 3.36 & مجــــال الإرشـــــاد \\
\hline .58 & 3.76 & .50 & 3.75 & .61 & 3.76 & .60 & 3.66 & 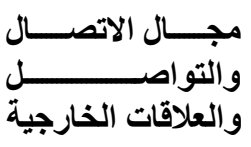 \\
\hline .64 & 3.84 & .55 & 3.85 & .64 & 3.82 & .65 & 3.74 & الثخخصــال الســــــات \\
\hline .67 & 3.69 & .48 & 3.67 & .62 & 3.71 & .66 & 3.37 & مجـــــال التوجيــــــ \\
\hline .81 & 3.55 & .54 & 3.62 & .65 & 3.72 & .69 & 3.55 & و التســـــل التوثيل \\
\hline .56 & 3.69 & .46 & 3.67 & .54 & 3.73 & .58 & 3.55 & الارجة الكلية \\
\hline
\end{tabular}

الجدول (8) تحليل التباين الأحادي (ANOVA) تقدير ات العينة لجميع المجالات وفقا لمتغير التخصص تفرير

\begin{tabular}{|c|c|c|c|c|c|c|}
\hline مستوى الدلالة & قيمة (فحس) & المربعا & الحرية & المربعات & مصدر التباين & المجالات \\
\hline \multirow[t]{2}{*}{.62} & \multirow[t]{2}{*}{.58} & .210 & 3 & .630 & بين المجمو عات & \multirow[t]{2}{*}{ الخطة الإرشادية } \\
\hline & & .361 & 307 & 110.948 & داخل المجمو عات & \\
\hline \multirow[t]{2}{*}{.24} & \multirow[t]{2}{*}{1.38} & .446 & 3 & 1.338 & بين المجموعات & \multirow{2}{*}{ الفردي ومهار اتهـ } \\
\hline & & .323 & 307 & 99.113 & داخل المجمو عات & \\
\hline \multirow[t]{2}{*}{.09} & \multirow[t]{2}{*}{2.14} & .981 & 3 & 2.943 & بين المجمو عات & \multirow[t]{2}{*}{ الإرشاد الجمعي } \\
\hline & & .456 & 307 & 140.145 & داخل المجمو عات & \\
\hline .89 & .20 & 7.044 & 3 & .211 & بين المجمو عات & الاتصــــال و التو اصــــلـ \\
\hline
\end{tabular}


IJASOS- International E-Journal of Advances in Social Sciences, Vol. VI, Issue 16, April 2020

\begin{tabular}{|c|c|c|c|c|c|c|}
\hline & & .343 & 307 & .105 .356 & داخل المجمو عات & و العلاقات الخارجية \\
\hline \multirow[t]{2}{*}{.91} & \multirow[t]{2}{*}{.17} & 7.020 & 3 & .211 & بين المجمو عات & \multirow{2}{*}{ الثخصية } \\
\hline & & .398 & 307 & 122.137 & داخل المجمو عات & \\
\hline \multirow[t]{2}{*}{.07} & \multirow[t]{2}{*}{2.28} & .840 & 3 & 2.519 & بين المجمو عات & \multirow[t]{2}{*}{ لتوجيه الجمعي } \\
\hline & & .368 & 307 & 112.956 & داخل المجمو عات & \\
\hline \multirow[t]{2}{*}{.29} & \multirow[t]{2}{*}{1.24} & .538 & 3 & 1.615 & بين المجمو عات & \multirow[t]{2}{*}{ التوثيق و التسجيل } \\
\hline & & .434 & 307 & 133.126 & داخل المجمو عات & \\
\hline \multirow[t]{2}{*}{.42} & .93 & .269 & 3 & .808 & بين المجمو عات & \multirow[t]{2}{*}{ مجموع المجالات } \\
\hline & & .288 & 307 & 88.487 & داخل المجمو عات & \\
\hline
\end{tabular}

تم حساب تحليل التباين الأحادي لتحديد الفروق بين مستويات التخصص في مدى تمكن الأخصسائي

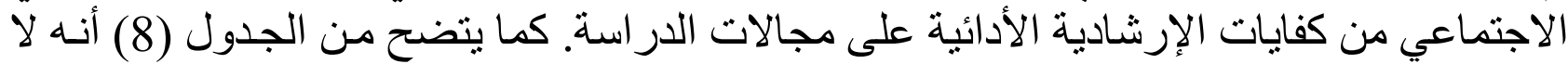

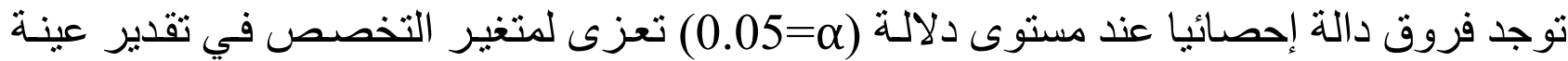

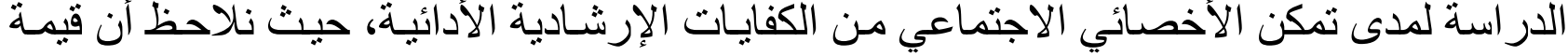

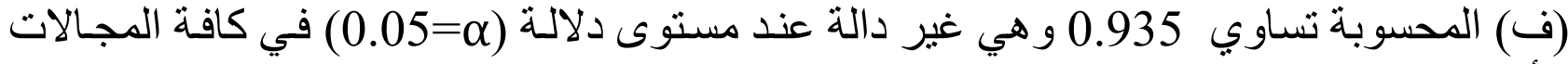

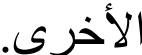

\section{قائمة المراجع العربية} أبو عبطة، سهام درويش (2002). مبادئ الإرشاد النفسي، ط2، دار الفكر للطباعة والنشر و التوزيع، الأردن،

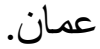
الأسدي، سعيد جاسم و إبر اهيم، مروان عبد المجيد(2003). الإرشـاد التربوي، مفهومـه، خصائصسه، ماهيته، الطبعة الأولى، الدار العلمية الدولية للنشر والتئ، عالتوزيع، عمان، الأردن. البحري، عبدالله بن سـالم بن ماجدا(2006). كفايـات المدرب بمراكز التدريب التابعة لـوزارة التربيـة والتعليم بسلطنة عمان، رسالة ماجستير غير منشورة، كلية التربية، جامعة السلطان قابوس، سلطنة عمان. البدوي، ححم(2005). المهارات السلوكية للأخصائي الاجتماعي. الطبعة الأولى، الإسكندرية، المكتب الجامعي

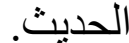

بر هم، نضال عبد اللطيف(2005). الخدمات الاجتماعية، ط1، الأردن، مكتبة المجتمع العربي للنشر. البطش، ححم، وجبريل موسى(2001). نموذج مقترح للإرشاد والتوجيه التربوي والمهني في الوطن العربي، لقاء خبر اء التوجيه المدرسي و المهني، البحرين، المنامة.

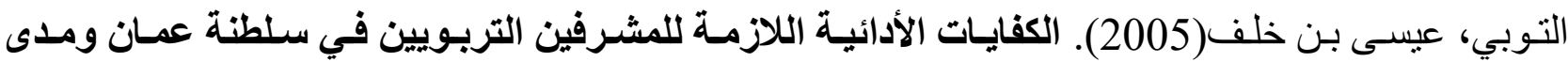
تمكنهم منها، رسالة ماجستير غير منشورة، جامعة القديس يوسف، بيروت.

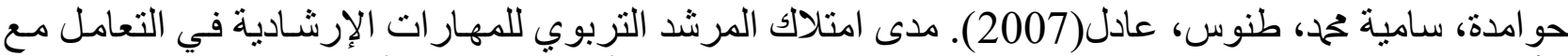
الأزمات في مدارس محافظات وسط الضفة الغربية (فلسطين). مجلة العلوم التربوية. العدد(13) 177-203. 
زريقي، سيف الدين فاروق(2008). الكفايات الإرشادية المدركة واختلافها باختلاف التأهيل والتدريب والخبرة وجنس المرشد في المدارس الأردنية، رسالة دكتور اه غير منشورة، الجامعة الأردنية، عمان، الأردن. السفاسفة، حمحد إبر اهيم(2005). إدر الك المرشدين التربويين لأهمية العمل في مجالات الإرشـاد(النمائي و الوقائي

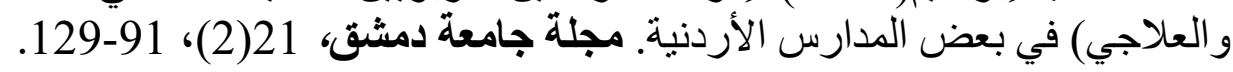

الثقصي، كاذية بنت راشد(2007). معوقات الممارسـة المهنية للأخصسائي الاجتمساعي في المجـال المدرسي، رسالة ماجستير غير منشورة، جامعة السلطان قابوس، كلية الآداب، سلطنة عمان. عبيدات، ذوقان و آخرون(2000). البحث العلمسي مفهومسه وأدواتهـ وأسـاليب، ط3، عمـان، دار أسـامة للنشر و التوزيع.

العصفور ، لميعة بنت داود(2004). الحاجات الإرشادية لطلبة المرحلة الثانوية في منطقتي مسقط والداخلية. رسالة ماجستير غير منشورة، جامعة السلطان قابوس، كلية التربية، سلطنة عمانة الإنة

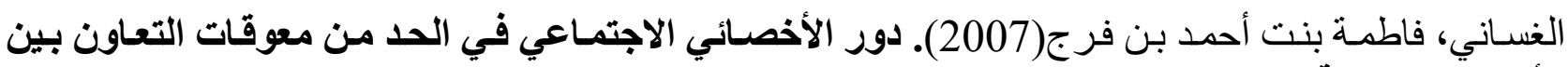

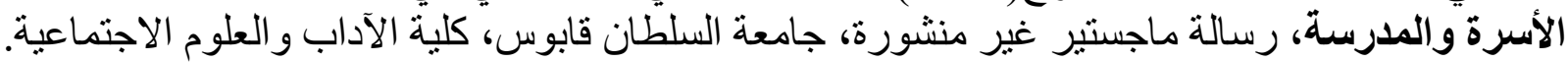

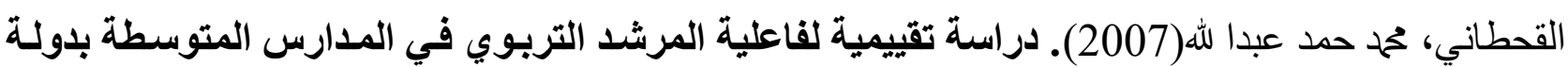
الكويث، رسالة ماجستير غير منشورة، جامعة عمان العربية للار اسات العليا، الأردن. المعشني، احمد علي(2001). خدمات الإرشـاد النفسي والتوجيه الدراسي والمهني في المـرحلتين الثانويـة

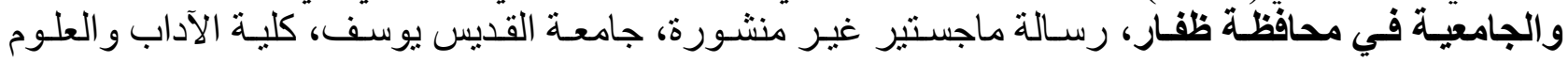
الإنسانية، بيروت.

النوفلي، حمود بن خميس(2006). دور الأخصسائي الاجتمـاعي في مواجهة المشكلات السلوكية في المجال

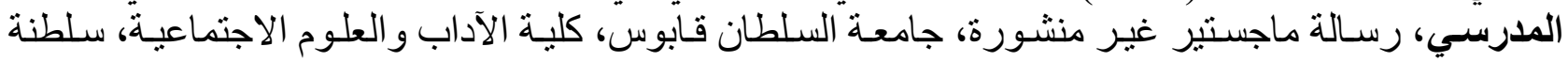
عمان.

\section{ARABIC REFERENCES IN ROMAN ALPHABET}

Abu Eitat, Saham Dirwish (2002). Mabadi Al'iirshad Alnafsi., T2, Dar Alfikr Liltabaeat Walnashr Waltawziei, Al'urduni, Eaman.

Al'asdiu, Saeid Jasim Wa'iibrahim, Marwan Eabd Almjid(2003). Al'iirshad Altarbuiu, Mafhumahu, Khasayisihu, Mahiatahu, Altibeat Al'uwlaa, Aldaar Aleilmiat Alduwaliat Lilnashr Waltawziei, Euman, Al'urdunn.

Albihriu, Eabdallah Bin Salim Bin Majd (2006). Kifaayat Almudarib Bimarakiz Altadrib Alttabieat Liwizarat Altarbiat Waltaelim Bisiltanat Eumaan, Risalat Majstayr Ghyr Manshurati, Kuliyat Altarbiati, Jamieat Alsultan Qabus, Saltanat Eaman.

Albidwi, Mahmd(2005). Almiharat Alsilukiat Lil'akhsayiyi Alaijtimaei. Altibeat Al'uwalaa, Al'iiskandariatu, Almaktab Aljamieiu Alhadith.

Barhum, Nidal Eabd Alltyf (2005). Alkhadamat Alaijtimaeiat, T1, Al'urdunu, Maktabat Almujtamae Alearabii Lilnashr. Albutshu,

Muhamid, Wajibril Musa (2001). Namudhaj Muqtarah Lil'iirshad Waltawjih Alturbuii Walmahnii fi Alwatan Alearabii, Liqa' Khubara' Altawjih Almadrasii Walmahnii, Albahrayni, Almunamat.

Altuwbi, Eisaa Bin Khalf (2005). Alkifayat Al'adayiyat Alllazimat Lilmushrifin Altarbuiiyn fi Saltanat Eamman Wamadaa Tumakinihim Minha, Risalat Majstayr Ghyr Manshurat, Jamieat Alqidiys Yusifu, Bayrut.

Huamidat, Samiat Muhamad, Tunwus, Eadl (2007). Madaa Aimtilak Almurshid Altarbwii Lilmiharat Al'iirshadiat fi Altaeamul Mae Al'azamat fi Madaris Muhafazat Wasat Aldifat Algharbia (Flastina). Majalat Aleulum Altarbawiat, Aleadd (13) 177-203.

Zariqi, Sayf Aldiyn Faruq (2008). Alkifayat Al'iirshadiat Almadrakat Waikhtilafaha Biaikhtilaf Altaahil Waltadrib 
Walkhibrat Wajuns Almurshid fi Almadaris Al'urduniyati, Risalat Dukturah Ghyr Minshurat, Aljamieat Al'urduniati, Euman, Al'urdunn.

Alsufasifat, Muhamad 'librahim (2005). 'lidrak Almurashadin Altarbuiiyn Li'ahamiyat Aleamal fi Majalat Al'iirshadi(Alnimayiyi Walwaqayiyi Waleilaji) fi Bed Almadaris Al'urduniyati. Majalat Jamieat Dimshuq, 21(2), 91-129.

Alshiqasi, Kadhiat Bnt Rashd (2007). Mueawiqat Almumarasat Almihniat Lil'akhsayiyi Alaijtimaeii fi Almajal Almadrisii, Risalat Majsatayr Ghyr Manshurat, Jamieat Alsultan Qabus, Kuliyat Aladabi, Saltanat Eaman.

Eubaydat, Dhawqan Wakharun (2000). Albahth Aleilmiu Mafhumah Wa'adawatih Wa'asaliba, Ta3, Eumaan, Dar 'Usamat Lilnashr Waltawzie.

Aleasfur, Limieat Bnt Dawd (2004). Alhajat Al'iirshadiat Latalabat Almarhalat Alththanawiat fi Mintaqatay Masqat Waldaakhiliati. Risalat Majstayr Ghyr Manshurat, Jamieat Alsultan Qabus, Kuliyat Altarbiati, Saltanat Eaman.

Alghisani, Fatimat Bnt 'Ahmad Bin Frj (2007). Dawr Al'akhsayiyi Alaijtimaeii fi Alhadi Min Mueawiqat Altaeawun Bayn Al'usrat Walmudrisati, Risalat Majstayr Ghyr Manshurat, Jamieat Alsultan Qabus, Kuliyat Aladab Waleulum Alaijtimaeiat.

Alqahtaniu, Muhamad Hamd Eabdana Lilha (2007). Dirasatan Taqyimiatan Lifaeiliat Almurshid Altarbwii fi Almadaris Almutawasitat Bidawlat Alkuayti, Risalat Majsatayr Ghyr Manshuratin, Jamieatan Eamman Alearabiat Lildirasat Aleulya, Al'urdunn.

Almaeshini, 'Ahmad Ealy (2001). Khadamat Al'iirshad Alnafsii Waltawjih Aldirasiu Walmahniu fi Almarhalatayn Alththanawiat Waljamieiat fi Muhafazat Zufari, Risalat Majsatayr Ghyr Manshurat, Jamieat Alqidiys Yusif, Kuliyat Aladab Waleulum Al'iinsaniati, Bayrut.

Alnuwfiliu, Hamuwd Bin Khamis (2006). Dawr Al'akhsayiyi Alaijtimaeii fi Muajahat Almushkilat Alsilukiat fi Almajal Almadrisii, Risalat Majsatayr Ghyr Manshurati, Jamieat Alsultan Qabws, Kuliyat Aladab Waleulum Alaijtimaeiati, Saltanat Eaman.

\section{REFERENCE LIST}

Carrol, B. (1993). Perceived Rolls and Perception Experiences of Elementary Counselors. Elementary school Guidance and Counseling, New York. 27. 216-226. 